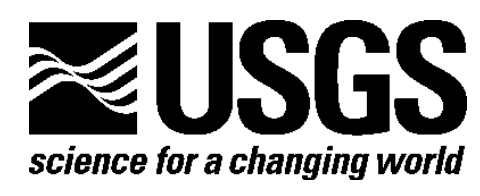

\title{
Workshop on New Madrid Geodesy and the Challenges of Understanding Intraplate Earthquakes
}

By Oliver S. Boyd, ${ }^{1}$ Eric Calais, ${ }^{2}$ John Langbein, ${ }^{3}$ Harold Magistrale, ${ }^{4}$ Seth Stein, ${ }^{5}$ and Mark D. Zoback ${ }^{6}$

1USGS, Memphis, Tenn.

2Purdue University, Ind.

3USGS Menlo Park, Calif.

4FM Global, USA

5Northwestern University, III.

${ }^{6}$ Stanford University, Calif.

Open-File Report 2013-1004

U.S. Department of the Interior

U.S. Geological Survey 


\section{U.S. Department of the Interior \\ KEN SALAZAR, Secretary}

\section{U.S. Geological Survey \\ Marcia K. McNutt, Director}

U.S. Geological Survey, Reston, Virginia: 2013

For product and ordering information:

World Wide Web: http://www.usgs.gov/pubprod

Telephone: 1-888-ASK-USGS

For more information on the USGS-the Federal source for science about the Earth, its natural and living resources, natural hazards, and the environment:

World Wide Web: http://www.usgs.gov

Telephone: 1-888-ASK-USGS

Suggested citation:

Boyd, O.S., Calais, Eric, Langbein, John, Magistrale, Harold, Stein, Seth, and Zoback, M.D., 2013,

Workshop on New Madrid geodesy and the challenges of understanding intraplate earthquakes: U.S. Geological Survey Open-File Report 2013-1004, 35 p.

Any use of trade, product, or firm names is for descriptive purposes only and does not imply endorsement by the U.S. Government.

Although this report is in the public domain, permission must be secured from the individual copyright owners to reproduce any copyrighted material contained within this report. 


\section{Contents}

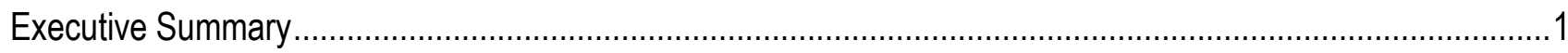

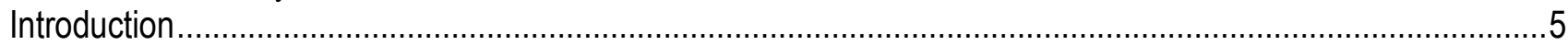

Presentation: The New Madrid Geodesy Workshop by Oliver Boyd .......................................................

Geodetic Estimates and Uncertainties.................................................................................................

Presentation: New Madrid Geodesy by Eric Calais ..............................................................................6

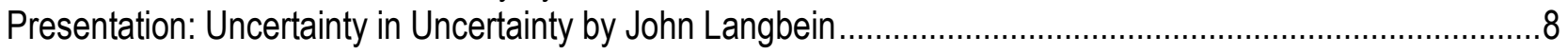

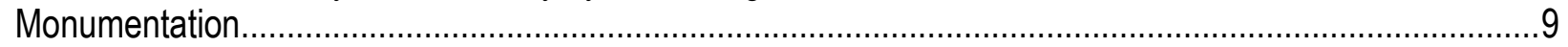

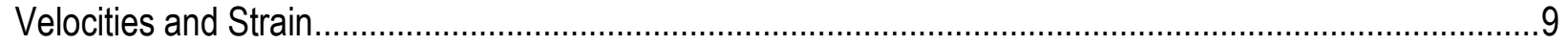

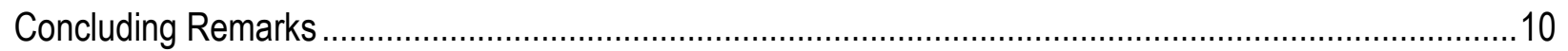

Strength and Stress ..............................................................................................................11

Presentation: State of Stress and Crustal Strength in the New Madrid Seismic Zone and Central and

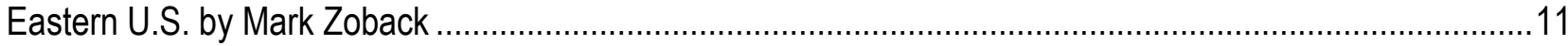

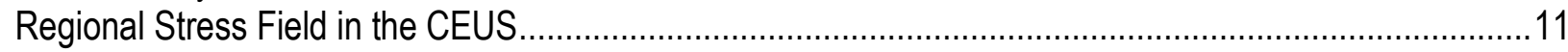

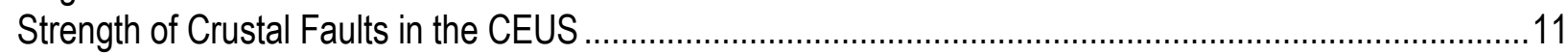

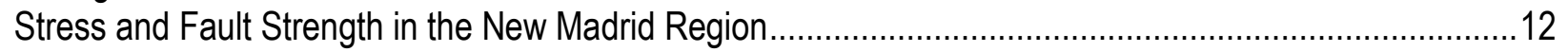

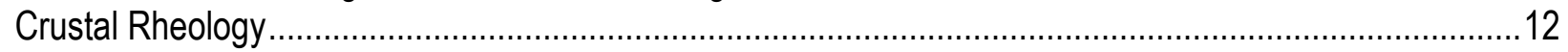

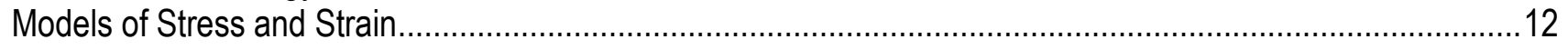

Presentation: An Overview of Models to Explain New Madrid Seismic Activity by Andy Freed......................13

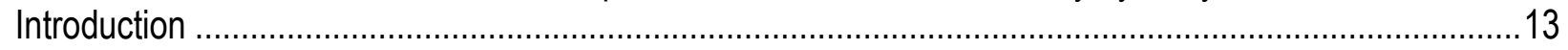

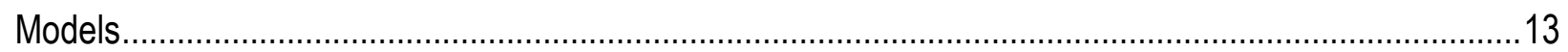

Sinking Rift Pillow .................................................................................................................

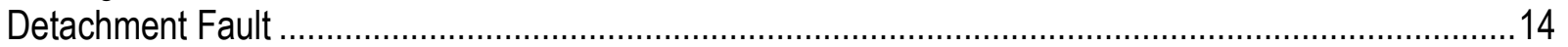

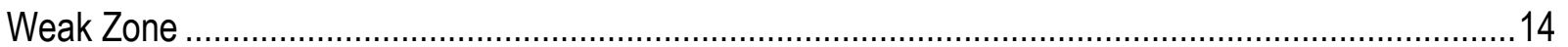

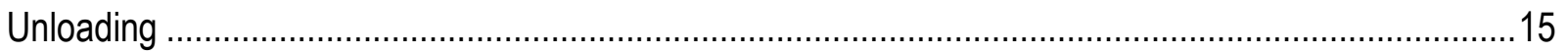

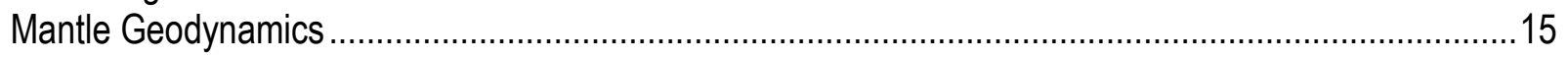

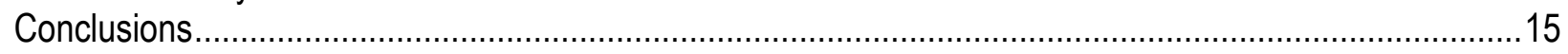

Presentation: Understanding mid-continent earthquakes: some challenges by Mian Liu..............................16

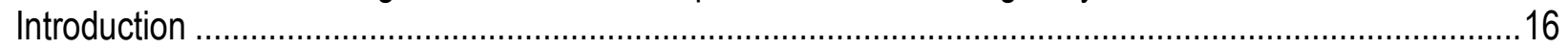

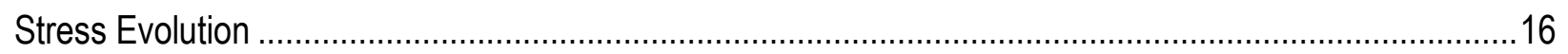

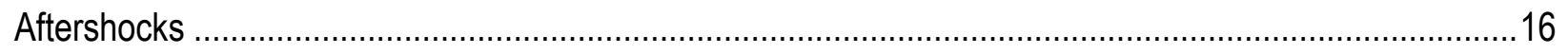

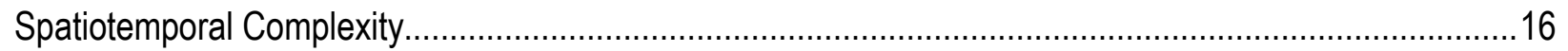

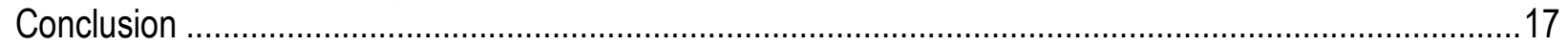

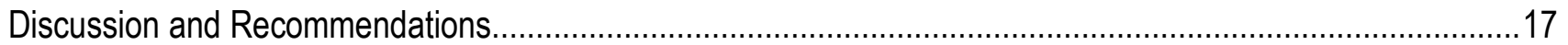

Campaign-style GPS measurements for the New Madrid Seismic zone; How much will they improve the

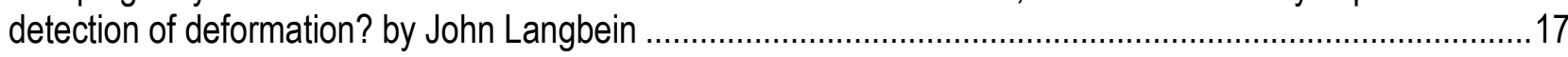

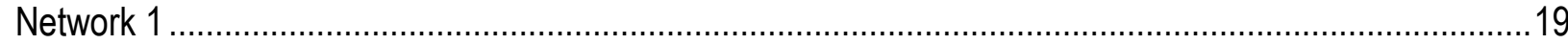

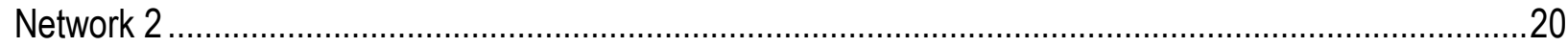

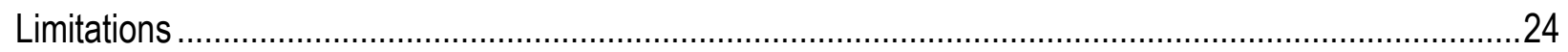

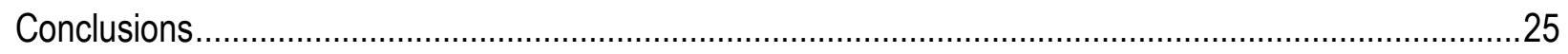

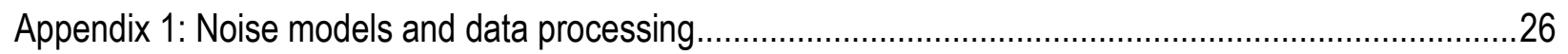

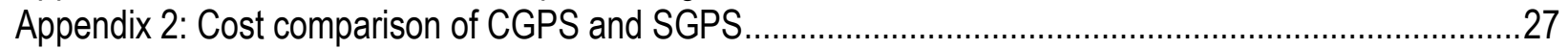

SGPS

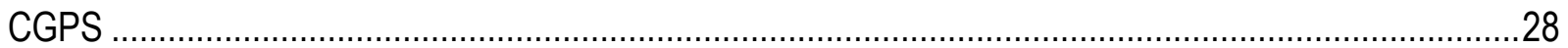

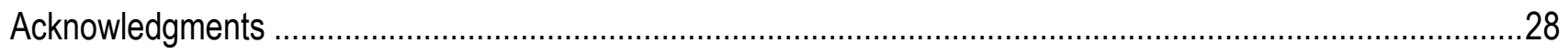

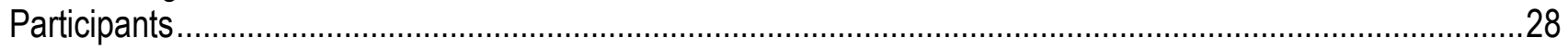


Software

\section{Figures}

Figure 1. Distribution of liquefaction features in the Upper Mississippi Embayment modified from figures $\mathrm{E}-5-\mathrm{E}-12$ of Tuttle and Hartleb (2012). The extent and compound nature of sand blows in the region suggest that the A.D. 900,1450, and 1811-1812 events had magnitudes between 7 and 8 and consisted of a cluster of two or more large earthquakes.

Figure 2. Global Positioning System velocity vectors and uncertainties for stations around the New Madrid seismic zone modified from figure 1 of Calais and Stein (2009)

Figure 3. Maximum horizontal stress orientations from focal mechanisms and borehole breakouts modified from figure 1 of Hurd and Zoback (2012). Stress orientations with thicker lines in and near the New Madrid seismic zone are presented in the Hurd and Zoback study

Figure 4. One of several models that may be used to explain the triggering of large earthquakes in the New Madrid seismic zone over the last several thousand years, adapted from figure 3 of Calais and others (2010)

Figure 5. New Madrid GPS sites depicted on regional (A) and local (B) scales ........................................18

Figure 6. Simulated campaign sites at regional (A) and local (B) scales ..................................................22

Figure 7. Same as figure $6 \mathrm{~B}$ but showing three linear SGPS networks spanning the NMSZ with monument spacing clustered at $12 \mathrm{~km}$ from fault to optimize resolution of locking depth (Langbein, 2008).......24

\section{Tables}

Table 1. Sensitivity of SGPS and CGPS to creep at depth in NMSZ-Figure 5 SGPS network

Table 2. Sensitivity of SGPS and CGPS to creep at depth in NMSZ; Future measurements as outlined in figure 6

Table 3. Sensitivity of SGPS and CGPS to creep at depth in the NMSZ; Future measurements as outlined in figure 7 .

Table A1.1. Noise components from NMSZ GPS network. Data processed using GIPSY; inter-quartile range and median. 


\title{
Workshop on New Madrid Geodesy and the Challenges of Understanding Intraplate Earthquakes
}

\author{
By Oliver Boyd, Eric Calais, John Langbein, Harold Magistrale, Seth Stein, and Mark Zoback
}

\section{Executive Summary}

On March 4, 2011, 26 researchers gathered in Norwood, Massachusetts, for a workshop sponsored by the U.S. Geological Survey and FM Global to discuss geodesy in and around the New Madrid seismic zone (NMSZ) and its relation to earthquake hazard. The group addressed the challenge of reconciling current geodetic measurements, which show low present-day surface strain rates, with paleoseismic evidence of recent, relatively frequent, major earthquakes in the region (fig. 1). Several researchers were invited by the organizing committee to give overview presentations while all participants were encouraged to present their most recent ideas. The overview presentations appear in this report along with a set of recommendations compiled by John Langbein. The remainder of this section summarizes the overview presentations and some of the discussion that resulted.

A fundamental observational constraint on intraplate strain is geodetic measurements of crustal deformation. The relative motions between most of the 55 Global Positioning System (GPS) station pairs in the NMSZ are less than $\sim 0.2 \mathrm{~mm} / \mathrm{yr}$ (fig. 2). The uncertainties are at best on the order of $0.2 \mathrm{~mm} / \mathrm{yr}$ but are challenging to reliably estimate. It was argued that two baselines within the NMSZ may show significant relative motions of $\sim 0.3-0.4 \mathrm{~mm} / \mathrm{yr}$. Some proposed that this reflects a physical process, others that it is the expected statistical behavior of a random distribution with zero mean.

Observations on stress and strength of the crust are important aspects of this problem. There is no difference in the orientation of principal stresses in the NMSZ with that of the surrounding region (fig. 3). Thus, the stress state in this region results from the same large-scale geologic processes stressing the central and eastern United States, and active faults in the NMSZ appear to have frictional strength similar to faults throughout the region. Further, limited available heat flow data do not show the NMSZ to be warmer (and thus weaker) than its surroundings. 


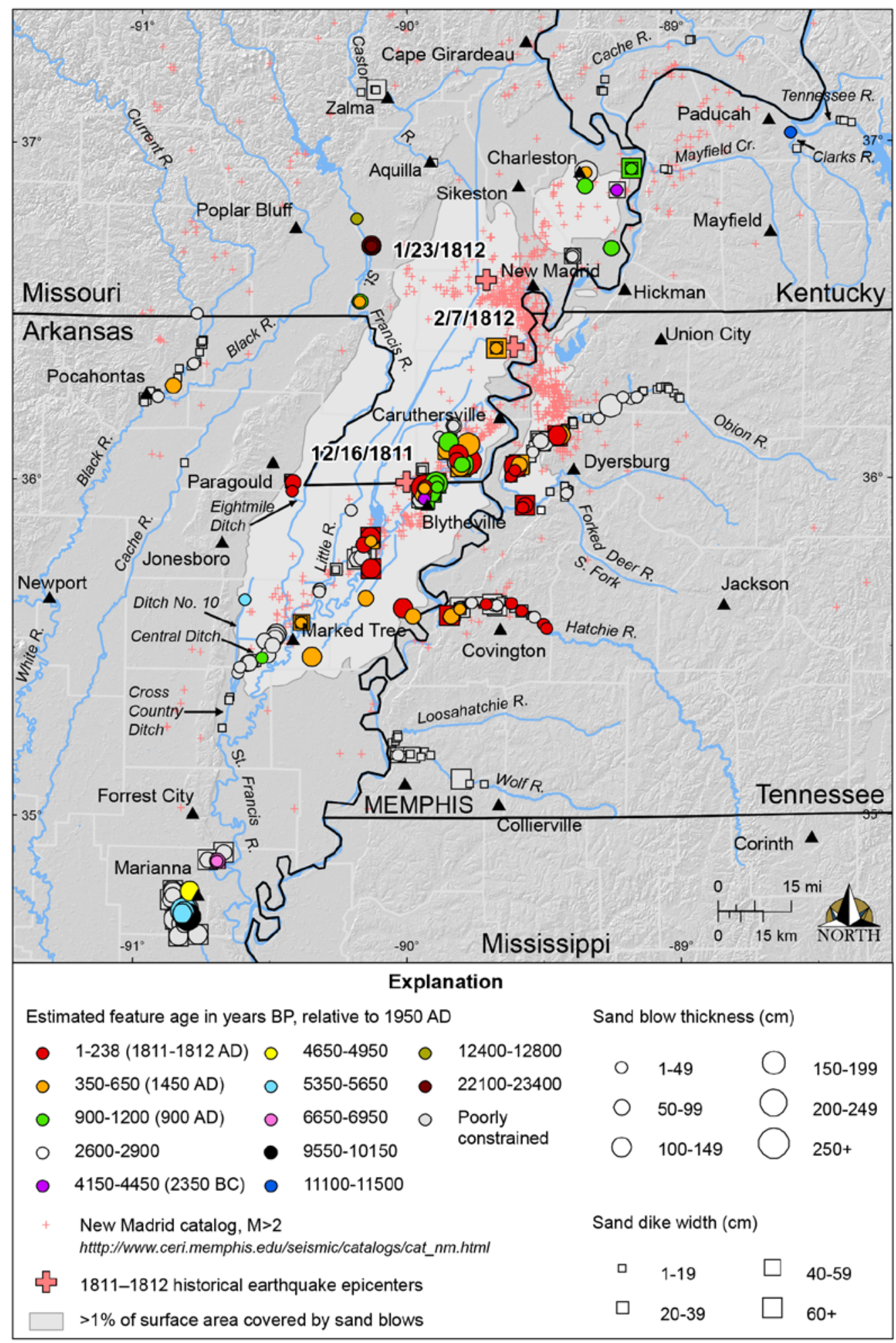

Figure 1. Distribution of liquefaction features in the Upper Mississippi Embayment modified from figures E-5-E-12 of Tuttle and Hartleb (2012). The extent and compound nature of sand blows in the region suggest that the A.D. 900, 1450, and 1811-1812 events had magnitudes between 7 and 8 and consisted of a cluster of two or more large earthquakes. 


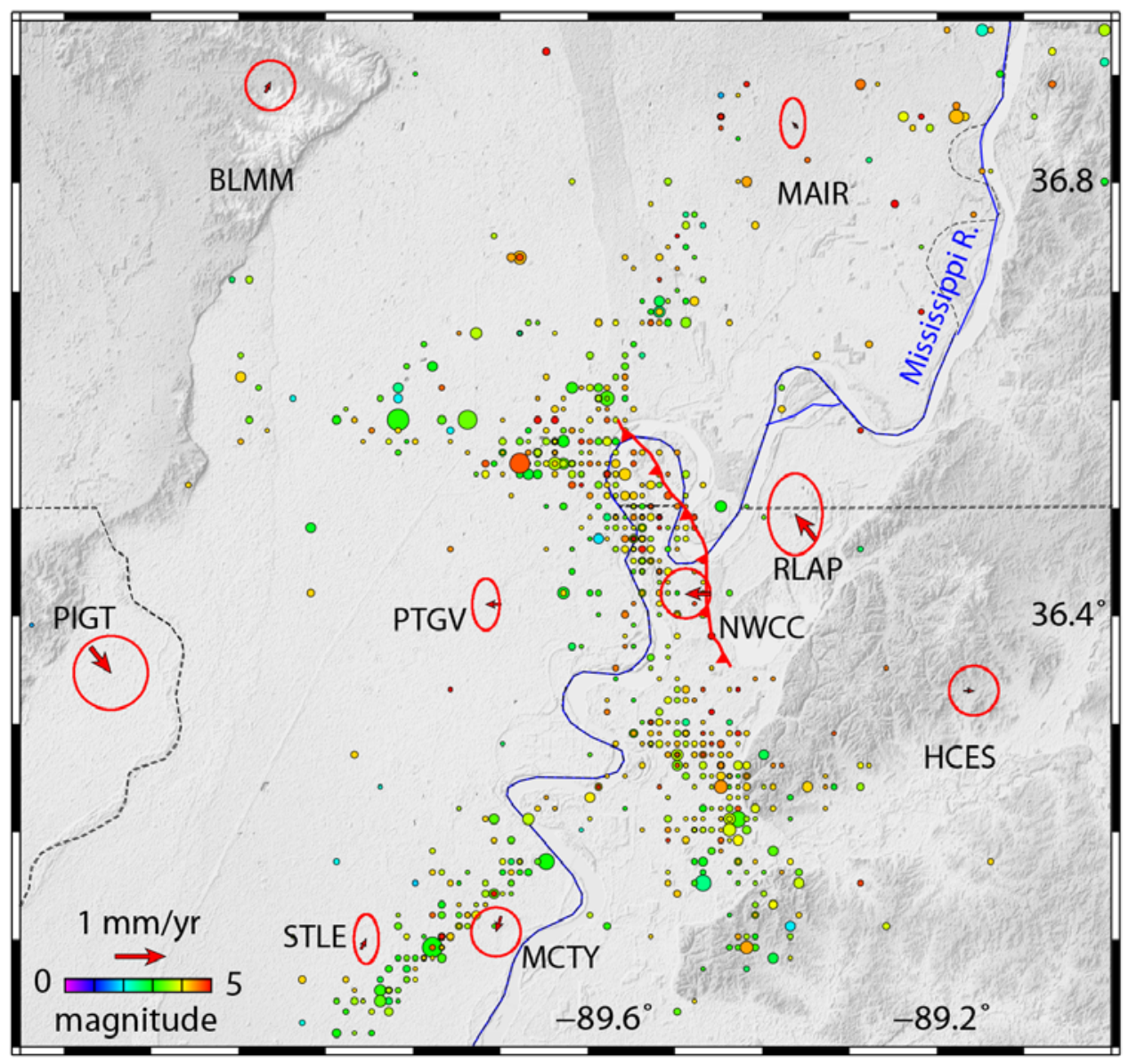

Figure 2. Global Positioning System velocity vectors and uncertainties for stations around the New Madrid seismic zone modified from figure 1 of Calais and Stein (2009). 


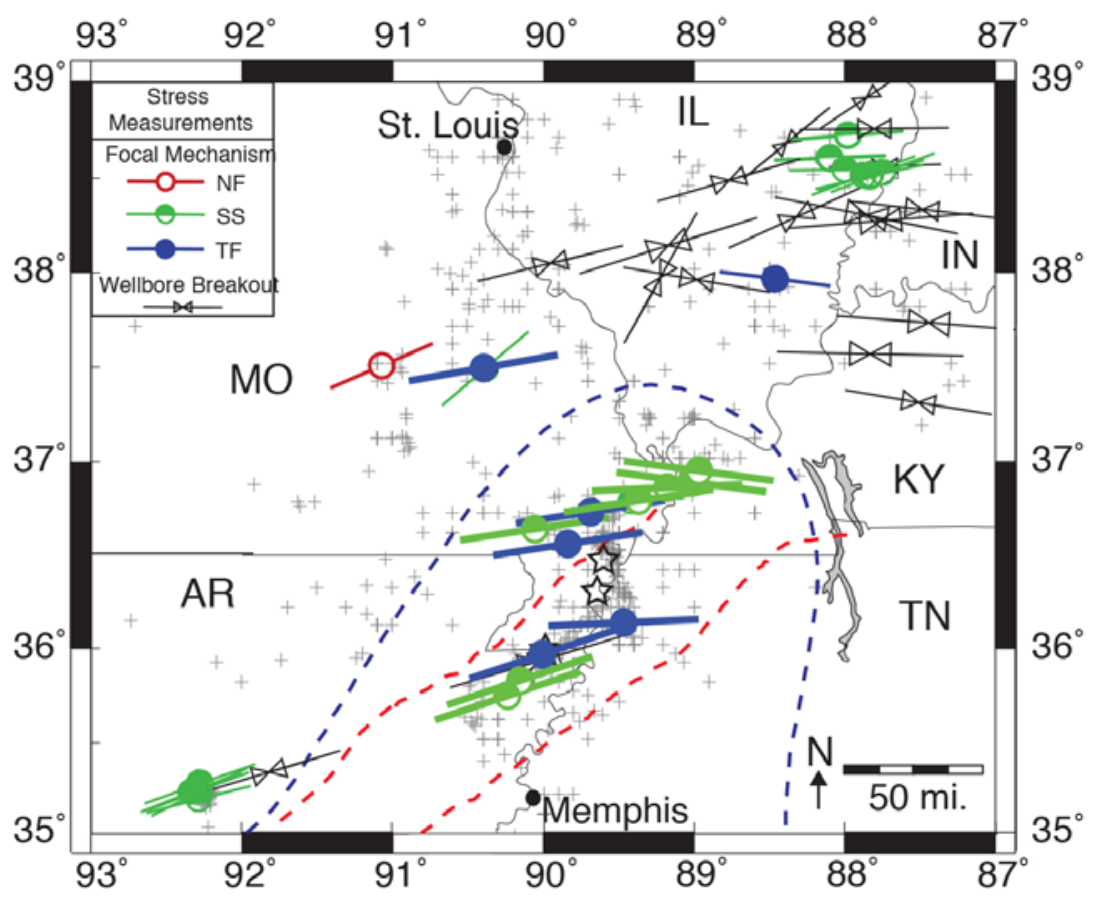

Figure 3. Maximum horizontal stress orientations from focal mechanisms and borehole breakouts modified from figure 1 of Hurd and Zoback (2012). Stress orientations with thicker lines in and near the New Madrid seismic zone are presented in the Hurd and Zoback study.

Models that relate low long-term strain to the occurrence of earthquakes in the NMSZ include those that invoke mantle convection, glacial isostatic adjustment, crustal heterogeneity, and erosion following retreat of the glaciers (fig. 4). However, these processes may be responsible for continued triggering of, rather than restoring the energy needed for, repeated large earthquakes. Furthermore, some researchers hypothesize that the next large earthquakes could occur on other faults in the region based on observations of earthquake migration in China and models of stress evolution following the 1811-1812 earthquakes. However, we lack the ability to tell if and when this might occur. 


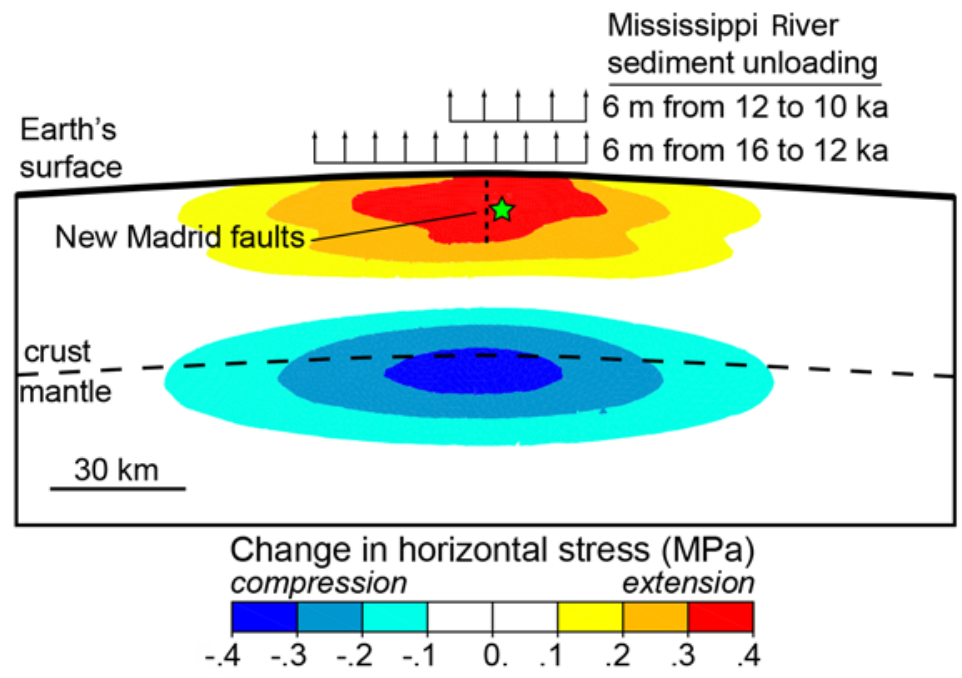

Figure 4. One of several models that may be used to explain the triggering of large earthquakes in the New Madrid seismic zone over the last several thousand years, adapted from figure 3 of Calais and others (2010).

Although there remains considerable uncertainty as to the ultimate driving force of these intraplate earthquakes, it is reasonable to expect that processes responsible for strain accumulation prior to 1811-1812 are still active today. Overall, the attendees agreed that the current density of geodetic monitoring is inadequate to address the apparent discrepancy between models inferred from geodetic and geologic data. In order to improve the testing of models of intraplate strain, geodetic monitoring should be densified in key locations by a combination of continuous and less-expensive episodic GPS deployments although calculations suggest that it will take several decades to be able to distinguish between alternative hypotheses. In conjunction, new physically based models of intraplate seismogenesis and data that constrain intraplate earthquake generation and recurrence are needed.

The Powerpoint slides that accompanied each of the following presentations can be accessed separately as PDF files by clicking on the title at the beginning of each overview presentation. In order to do this, the presentation files must first be downloaded from the publication index page at http://pubs.usgs.gov/of/2013/1004 and placed in the same folder as the downloaded report.

\section{Introduction}

\section{Presentation: The New Madrid Geodesy Workshop by Oliver Boyd}

During the winter of 1811-1812, there were three large earthquakes between magnitudes 7 and 8 that occurred near the town of New Madrid in the Bootheel region of Missouri (slide 2). There were thousands of aftershocks in the days to months following these devastating earthquakes.

Evidence of past large earthquakes in the region (slide 3) includes vast sand blow fields covering thousands of square kilometers (Tuttle and others, 2005), changes to meanders of the Mississippi River (Holbrook and others, 2006) and damage to speliothems (Panno and others, 
2009; J. Tinsley, 2011, written commun.). Dating of these events and regional correlation suggest large earthquakes occurred several times over the last 20,000 years including events $\sim 16,000$ B.C., 11,500 B.C., 10,000 B.C., 3500 B.C., 2350 B.C., 1620 B.C., A.D. 300 , A.D. 900, A.D. 1450, and A.D. 1811-1812 (slide 4). The return period of the most recent well-studied events is on the order of 500 years.

Geodetic data may be able to give us some insight into whether return periods of 500 years are reasonable for a magnitude 7-8 earthquake. The most recent analysis (Calais and Stein, 2009) reveals exceptionally low amounts of strain across the New Madrid seismic zone over the last decade (slide 5), which is inconsistent with a magnitude 7 or above earthquake having a return period of 500 years, assuming a plate boundary type of fault strain storage. Further, they suggest the strains are not significantly different from zero.

In this workshop, we explore: (1) whether there are significant Global Positioning System (GPS) measured strains in the New Madrid region; (2) if the strains or lack of strain is consistent with expectations; (3) how we can improve the monitoring network to prove or disprove hypotheses; and (4) what are the implications for hazard.

\section{Geodetic Estimates and Uncertainties}

Presentations were given by Eric Calais and John Langbein to review the status of geodetic measurements in the region including their magnitudes and uncertainties.

\section{Presentation: New Madrid Geodesy by Eric Calais}

The New Madrid seismic zone is the only "active" intraplate seismic zone with a local continuous GPS monitoring system (slide 2). This system is composed of three networks: the GPS Array for mid America (GAMA) run by the Center for Earthquake Research and Information (CERI) consisting of H-beam and deep-drilled braced monuments; the Continuously Operating Reference Stations (CORS) run by the National Geodetic Survey consisting of stations attached to buildings, masts and pillars; and various stations attached to buildings and fence posts run by the National Oceanic and Atmospheric Administration's (NOAA) Forecast Systems $\mathrm{Lab}$ (FSL).

As more and more data have been acquired in the region (slide 3), estimates of deformation have exponentially approached zero with the majority of estimates being insignificantly different from zero. This is not surprising and is expected for an intraplate region. It is therefore important to properly quantify the level of uncertainty associated with these velocity and strain rate measurements.

Measurements in intraplate regions affected by glacial isostatic adjustment (GIA), such as northern Europe (slide 4), show results consistent with GIA models, even though velocities are 1 $\mathrm{mm} / \mathrm{yr}$ or less and strain rates are on the order of $10^{-9} \mathrm{yr}^{-1}$. GPS can therefore detect with confidence such a low level of intraplate deformation, if it exists. (slide 5):

The GPS data for North America are processed according to the following procedure

1) Phase data are processed with the software program GPS Analysis at the Massachusetts Institute of Technology (GAMIT) and include Absolute Phase Center models, reprocessed International GPS Service (IGS) orbits, and the 2008 International Terrestrial Reference Frame (ITRF2008). 
2) Position time series are used for outliers/jumps detection and for calculating the parameters of a white plus colored noise model ("realistic sigma" algorithm; Herring, 2003).

3) Daily solutions are combined into weekly position solutions.

4) Weekly solutions are combined with weekly IGS solutions from MIT into one cumulative position/velocity solution (loosely constrained).

5) The ITRF2008 reference frame is implemented by minimizing position/velocity deviation from a core group of globally distributed IGS stations.

6) A North America (NOAM)-plate frame is implemented by removing rigid plate rotation based on stable NOAM sites.

The resulting time series (slide 6) show many good and some bad (RLAP, NWCC) or ugly (HCES, PIGT) stations. Some show a strong seasonal signal, some several gaps. Obviously there is variability in overall time series length depending on the age of the site.

It is well known that uncertainties in the position and velocity of GPS stations result from a combination of white and colored noise (slide 7). If noise in the time series were purely white, formal uncertainties would be exceedingly small. However, colored noise, including flicker and random walk (whose sources remain debated but may include unmodeled atmospheric noise), leads to far greater formal uncertainties. Uncertainties on horizontal velocities for the stations in the New Madrid region estimated with the software programs Create and Analyze Time Series (CATS; Williams, 2008) and Global Kalman filter VLBI and GPS analysis (GLOBK; Herring and others, 1986) are generally between 0.1 and $0.3 \mathrm{~mm} / \mathrm{yr}$. They agree very well between the two independent noise analysis methods. They reach up to $1 \mathrm{~mm} / \mathrm{yr}$ for sites HCES and NWCC (slide 8). Therefore, uncertainties are generally many times larger than the relative or absolute (for example, with respect to a NOAM frame) motions of the stations (slide 9). These motions exceed their 95 percent confidence interval at sites RLAP and PIGT only; two sites whose position time series are particularly noisy (slide 6).

A similar analysis repeated since June 2005, shows that velocity uncertainties have decreased by at least a factor of 2 for all sites (slide 10). Velocity residuals have decreased by about a factor of 3, and remain insignificantly different from zero (slide 11). This holds whether one considers the broader Upper Mississippi region or the New Madrid seismic zone only. PIGT and RLAP are consistent outliers, the former due to significant amounts of colored noise and the latter due to large gaps in their position time series.

Strain rate across the entire New Madrid region is less than $10^{-9} \mathrm{yr}^{-1}$ and insignificantly different from zero, as already found in 2008 (slide 12). We also consider all of the possible baselines between stations (slide 13) and find that only 2 of the 55 baselines show a rate of change that is greater than the 95 percent confidence limit (PTGV-MCLE and PTGV-MCTY). Likewise, strain rates within subregions are generally less than their uncertainty and never significantly different from zero at a confidence level greater than 80 percent (slide 14).

To conclude, it appears that the longer we measure the New Madrid region with GPS, the smaller the relative velocities and strain rates become, currently at $0 \pm 0.2 \mathrm{~mm} / \mathrm{yr}$ and less than $10^{-9} \mathrm{yr}^{-1}$, respectively (slide 15). Therefore, if one assumes a plate boundary, steady-state strain accumulation and release model, the current surface strain rate is too small to sustain M7 events every 500 years. But significant questions remain. If there is currently zero strain rate, does that mean zero hazard? If there is ongoing strain, where is it? Under the New Madrid seismic zone, decoupled from the surface or spread out over a wider region and currently undetectable with GPS? Are RLAP and PIGT showing reliable tectonic signals? Finally, we can only measure 
current strain rates with GPS. What if the New Madrid seismic zone or midcontinent had been loaded long ago and is currently unloading fossil strain through a recently triggered aseismic activity (Calais and others, 2010)?

\section{Presentation: Uncertainty in Uncertainty by John Langbein}

Paraphrasing ex-Secretary of Defense Rumsfeld, "Uncertainty in Uncertainty." The uncertainty of the GPS velocities is also uncertain. Here, GPS data from the central United States are processed with the software program GNSS-Inferred Positioning System (GIPSY)(Zumberge and others, 1997) in order to estimate the background noise, monument stability, velocities and strain rates. Finally, an outline for strategies to improve the signal to noise ratio is given.

The sites on the map (slide 4) are analyzed using the U.S. Geological Survey (USGS) implementation of GIPSY with regional filtering as described by Hammond and Thatcher (2007). Circled locations are sites used to implement the regional filter; an attempt is made to have good geographic coverage, long time series, and "good" data. Nonetheless, even with the regional filter, there still were significant common-mode signals. Using the time series of several sites closer to the New Madrid region (circled sites in slide 5), the north, east, and, up time series are "stacked" to determine the average translation with time. The average translation is then subtracted from all of the time series.

Slide 6 shows a sequence of improvement with processing the data: LEFT-The results of standard GIPSY processing with no filtering or editing; MIDDLE_-Removing outliers, bad data, and offsets; and RIGHT-Using the regional filter; these results are available on the USGS web site http://earthquake.usgs.gov/monitoring/gps/CentralUS/. The time series can be further improved by regional or common mode filtering (slide 7).

A general discussion of estimating geodetic velocities and their uncertainties is contained in Langbein (2012) and references therein. The relevance of that discussion applied to the New Madrid GPS data can be summarized as:

1. During the past decade, it has been determined that time series of geodetically measured positions (for example, GPS) have significant temporal correlations that are due to a number of factors including the localized displacements of the monuments, incomplete modeling of satellite orbits and tropospheric delays, signal multi-path, etc. In the frequency domain, the temporal correlations are described by a "red" spectrum.

2. The estimate of velocity and in particular, the uncertainty of the velocity (the error bar) depends upon the character of the spectrum at its longest periods. With a limited interval of time spanned by the observations, the long period component is poorly constrained. The intermediate and short-period components are better constrained.

3. The poorly constrained, long-period part of the spectrum can lead to a factor of 2 difference in the uncertainty of the estimated error in velocity.

4. The two competing models of temporal correlation are: A) power law (PL), where the red spectrum is characterized as a function of frequency, $1 / \mathrm{f}^{\mathrm{n}}$, where $\mathrm{n}$ is the spectral index and, for GPS data, ranges between 1 and 2; and B) where spectrum is described by a combination of two power laws, one being flicker $(n=1)$ and the other being random walk $(\mathrm{n}=2)$ (FLRW). Detecting the presence of the randomwalk component is the most difficult as it characterizes the correlation at the longest periods. 
5. With the small signals of deformation measured with GPS across the New Madrid region, factors of two variations in the rate uncertainty can cause one to accept or reject the presence of detectable strain accumulation.

\section{Monumentation}

Are the "engineered" monuments used in the eastern U.S./Canada better or worse than those used in California? In some cases, GPS sites in the central and eastern U.S. are installed on fence posts (slide 30). The fence post sites are NOAA sites operated by the National Geodetic Survey (NGS) used for atmospheric remote sensing; the GPS is primarily used for water vapor, and there is other equipment on-site (http://www.gpsmet.noaa.gov/background.html). In other cases, they are braced with steel pipes extending several meters into the ground. Another important consideration is whether the Center for Earthquake Research and Information (CERI) site domes have been changed to Southern California Integrated GPS Network (SCIGN) domes.

Measurement of monument stability can be determined by:

1) Assuming an optimal noise model in terms of maximum likelihood

2) Using noise parameters from optimal noise model

3) Assuming 5 years of GPS, daily sampled data

4) Computing rate uncertainty using parameters from optimal noise Slide 31 shows the rate-error for Central U.S. sites in red and SCIGN sites in black/gray. Excluded from SCIGN are Nevada results and those in the Los Angeles basin, Calif., affected by local pumping. Pair-wise rank testing suggests that CERI monuments as a group are less stable, in many cases at the 99-percent level. For a comparison of braced monuments, SCIGN and CERI monuments perform equally well. Given the sensitivity of rate uncertainty to the functional form of the noise model (in other words, PL vs. FLRW), one needs to be cautious with the ratemetric used; consequently any conclusions drawn here are preliminary.

There now exist two sites in the NMSZ that have deep brace monuments (slide 32). Unfortunately, these sites have only been in place for a few years so the uncertainty of the rate uncertainty is relatively high. Interestingly, three sites that were used as part of a collection of sites for constructing a regional filter (slide 33) show low noise relative to the other sites; the site logs indicate that these are cement piers anchored to bedrock.

In the mid 2000's, Mattioli installed braced monuments next to CERI monuments (slide 34). These were operated for about one year. A comparison of changes in baseline length suggests that the braced monuments are more stable than the CERI monuments; lacking the data from Mattioli and the shortness of these time-series, the test is probably not conclusive.

\section{Velocities and Strain}

The resulting velocity map (slide 35 ) shows the velocity vectors and their 1-sigma uncertainties; the uncertainties are computed on the basis of selecting the optimal noise model. Velocities are relative to North America (NA) with a small, $<1 \mathrm{~mm} / \mathrm{yr}$ translation removed.

The resulting GPS velocity vectors suggest contraction across the NMSZ (slide 36). Estimating the strain rates is limited to sites on this map and includes PIGT. Using rates and their errors for stations on this map yields:

$$
\begin{aligned}
& \mathrm{E}_{\mathrm{ee}}=-22 \pm 4 \mathrm{~ns} / \mathrm{yr} \\
& \mathrm{E}_{\mathrm{nn}}=+1 \pm 4 \mathrm{~ns} / \mathrm{yr} \\
& \mathrm{E}_{\mathrm{en}}=-4 \pm 3 \mathrm{~ns} / \mathrm{yr}
\end{aligned}
$$


These strain rates are dominated by the apparent high signal to noise ratio (SNR) from the 2 sites with braced monuments; these have only $\sim 3$ years of data and noise modeling tends to support a FL noise model. Using a more conservative rate uncertainty for those sites and not using PIGT reduces $\mathrm{E}_{\mathrm{ee}}$ to $-5 \pm 4 \mathrm{~ns} / \mathrm{yr}$. The GIPSY analysis of the NMSZ sites suggests a 4 ns/yr uncertainty. Examination of the E. Calais solution (written commun., 2011) suggests about a 2 ns/yr limit. All uncertainties are 1-sigma.

Slide 37 shows a comparison of site velocities from various sources: Upper left-Using GIPSY estimates of position change and a noise model of WN + FL + RW; Upper right-Using estimates of position change provided by E. Calais and a noise model of WN + FL + RW; Lower left_-Using estimates of position change provided by E. Calais and a noise model of WN + FL. In this case no RW was estimated. Note the reduction in error ellipses; Lower right-E. Calais' estimate of velocities under the probable assumption of a WN + FL model. Note that error ellipses are similar to those in the lower left figure. With the use of a noise model without RW, E-W contraction is apparent at PIGT/RLAP and to a lesser extent with PIGT/HCES. Elimination of those sites reduces the estimated EW contraction to be insignificant.

Estimates of strain change were provided by Duncan Agnew (written commun., 2011) (slide 38). For the $\sim 10$ years of data, an MLE analysis was performed with five noise models (all having some component of white noise): FL, RW, PL, FL+RW, and either FL+BandPass or $\mathrm{RW}+$ BandPass. For $\mathrm{E}_{\mathrm{ee}}$, the simplest noise model is $\mathrm{RW}$ with $18.2 \mathrm{~ns} / \mathrm{yr}^{0.5}$. For $\mathrm{E}_{\mathrm{ee}}$ and $\mathrm{E}_{\mathrm{en}}$, the simplest model is FL noise. But, there is some improvement in "fit" if either FLRW or PL noise is used. Perhaps more importantly, the RW component, although not necessarily statistically important, has a big impact (factor of 3) on the estimated uncertainty in strain rate; hence, for simplicity, RW amplitudes are reported for the uncertainty, $\varepsilon$ :

$$
\begin{aligned}
& \varepsilon_{\mathrm{nn}}=5.3 \mathrm{~ns} / \mathrm{yr}^{0.5} \\
& \varepsilon_{\mathrm{en}}=3.6 \mathrm{~ns} / \mathrm{yr}^{0.5}
\end{aligned}
$$

These uncertainties translate to rates of:

$$
\begin{aligned}
& \mathrm{E}_{\mathrm{ee}}=-2.2 \pm 5.5 \mathrm{~ns} / \mathrm{yr} \\
& \mathrm{E}_{\mathrm{nn}}=+0.1 \pm 1.6 \mathrm{~ns} / \mathrm{yr} \\
& \mathrm{E}_{\mathrm{en}}=-1.8 \pm 1.2 \mathrm{~ns} / \mathrm{yr}
\end{aligned}
$$

Instead of using the time series of strain provided by Duncan Agnew, the site velocities for these same sites can be used to estimate the strain rate (plus network translation and rotation). This calculation yields:

$$
\begin{aligned}
& \mathrm{E}_{\mathrm{ee}}=+3.0 \pm 6.7 \mathrm{~ns} / \mathrm{yr} \\
& \mathrm{E}_{\mathrm{nn}}=+0.3 \pm 2.8 \mathrm{~ns} / \mathrm{yr} \\
& \mathrm{E}_{\mathrm{en}}=-1.5 \pm 3.1 \mathrm{~ns} / \mathrm{yr}
\end{aligned}
$$

Differences between these two sets of estimates are due, in part, to the underlying data selected. For Agnew's time series of strain, he selected days for which observations were present for all sites. This stringent requirement was not used to obtain site velocities.

\section{Concluding Remarks}

Items to consider (slides 39, 40):

Short-term items:

- Why does PIGT drift east?

- Install second site at/near PIGT

- Monitor tilt of PIGT pier

- Persistent scatter InSar near PIGT 
- Reactivate the Mattioli sites; HCES and PGTV

- Replace antenna at HCES (noisy)

- Redo USGS solutions to obtain better precision

Long-term items:

- Campaign/Survey mode GPS

- Additional continuous GPS, where?

\section{Strength and Stress}

A presentation was given by Mark Zoback to discuss issues related to the strength and stress in the crust of central and eastern North America and the New Madrid region in particular.

\section{Presentation: State of Stress and Crustal Strength in the New Madrid Seismic Zone and Central and Eastern U.S. by Mark Zoback}

This presentation provides an update on the regional stress field of the central and eastern United States (CEUS) based on 10 stress inversions (Mazzotti and Townend, 2010) and 52 new well-constrained focal-plane mechanisms (Hurd and Zoback, 2012). Additionally, the strength of crustal faults in the CEUS (Hurd and Zoback revisiting M.L. Zoback (1992)), stress and fault strength in the New Madrid region, and crustal rheology are discussed.

\section{Regional Stress Field in the CEUS}

In 1981, Zoback and Zoback (1981) published a paper entitled "State of Stress and Intraplate Earthquakes in the United States" (slide 3). They found that fault slip in New Madrid is geometrically consistent with regional ENE-WSW compression and Coulomb faulting theory.

Over most of the CEUS, stress orientations are relatively uniform across complex geologic boundaries (slide 4). Intraplate earthquakes in this region appear to result from the contemporary stress field acting on pre-existing faults (Zoback and Zoback, 1980; Zoback and Zoback, 1989).

There has been little progress in mapping intraplate stress in the CEUS over the last 20 years (slide 5). Recently, Mazzotti and Townend (2010) used a Bayesian analysis of earthquake focal mechanisms to determine the state of stress in areas of high seismicity (for example, fault zones, failed rifts, suture zones, etc.; areas that have been known to exhibit elevated seismicity for the last 30 or 40 years throughout the world). Slide 6 shows the focal mechanisms used in their study. Gray lines indicate the Iapetus rifted margin and failed rifts.

Hurd and Zoback examined 52 focal mechanisms in the CEUS (slide 7). The mechanisms are highly consistent with a NE-SW compressive stress, but there are some notable rotations.

Relative stress magnitudes can be mapped to give an indication of whether stresses promote strike-slip, normal, or thrust faulting (slide 8). Focal mechanisms transition from normal in the western part of the study area to strike-slip in the center to thrust in the east (slide 9) and indicate a steady transition in the state of stress.

Strength of Crustal Faults in the CEUS

Townend and Zoback (2000) argued that intraplate faults were strong based on observations from deep boreholes worldwide that show the persistence of hydrostatic pore pressures to great depth, high bulk permeability, and a high coefficient of friction (slide 11). 
Fault strength can also be assessed from stress and fault orientations (slide 12). The friction on a fault will define the orientation between the stress field and optimally oriented fault planes assuming the Mohr-Coulomb criterion. For each focal mechanism, there are two possible planes with only a subset of orientations that are compatible with the orientation of stress acting on the fault (slide 13). For an example in NW Texas, only one plane is compatible with the stress field and implies a coefficient of friction of about 0.7 . One could then ask for each focal mechanism: Which plane is compatible with a coefficient of friction near 0.6 and how far rotated is this plane from an optimum orientation? This analysis yields mean deviations, relative to an optimally oriented fault having a coefficient of friction of 0.6 , of 7 and 10 degrees of the strike and dip, respectively, with standard deviations on the same order (slide 15). Orientations of the conjugate plane have much larger mean and standard deviations.

In summary, new data points confirm consistent NE-SW $\mathrm{S}_{\mathrm{Hmax}}$ in most of the CEUS (but there are exceptions). Horizontal stresses become increasingly compressive moving from the central U.S. to the northeastern U.S. and SE Canada. Slip on faults is compatible with a coefficient of friction of 0.6 on preferred nodal planes in the regional stress field. So what about the New Madrid region?

\section{Stress and Fault Strength in the New Madrid Region}

Focal mechanisms and inversions within the New Madrid region by Hurd and Zoback (2012) and those of Mazzotti and Townend (2010) are consistent with the overall stress field having $\mathrm{S}_{\mathrm{Hmax}}$ oriented NE-SW (slides 17, 18). Further, focal mechanisms are consistent with high values of fault friction.

\section{Crustal Rheology}

Earthquakes occur over much of the CEUS (slide 21). This can occur if brittle failure occurs in a crust in failure equilibrium, which results from the crust being critically stressed by creep in the lower crust and upper mantle (slide 22). The crust is likely very strong with viscosities greater than $10^{22} \mathrm{~Pa} \mathrm{~s}$ under dry conditions, a range of plausible temperature profiles, and a strain rate of $10^{-9} \mathrm{yr}^{-1}$ (slide 23; Calais and others, 2010).

But could there be a localized weak zone in the upper mantle beneath the New Madrid region? (slide 24; Grollimund and Zoback, 2001) And if so, how would this region deform in response to the regional stress? Before glaciation, strain rates were likely less than $10^{-12} \mathrm{yr}^{-1}$. Following glaciation and a weakened upper mantle, strain rates could be as high as $10^{-9} \mathrm{yr}^{-1}$. One event that could have helped to weaken the upper mantle was the passing of the Bermuda hot spot (slide 25; Cox and Van Arsdale, 2002). This event may also have influenced earthquakes in Charleston, South Carolina. Consequently, it is likely that geologic history and inheritance of potential seismogenic structures is important.

\section{Models of Stress and Strain}

Andy Freed and Mian Liu presented material concerning existing models that may explain seismicity within the New Madrid region. 


\section{Presentation: An Overview of Models to Explain New Madrid Seismic Activity by Andy Freed}

Introduction

The eastern California shear zone has strain rates of $10^{-7} \mathrm{yr}^{-1}$ and recurrence intervals on the order of several thousand years while the CEUS has strain rates less than $10^{-9} \mathrm{yr}^{-1}$ but recurrence intervals of $\sim 500$ years in the NMSZ (slide 1). Are there models that are consistent with this behavior?

Some researchers have sought models of fault reactivation to explain seismicity within the New Madrid region (slide 2). The orientation of the NMSZ, the earthquake focal mechanisms, the correlation of the trend of seismicity with the buried Reelfoot rift, and the nearly east-west compressive stress field of the New Madrid region are consistent with the reactivation of ancient faults (Sbar and Sykes, 1973; Sykes, 1978; Zoback and Zoback, 1981; Braile and others, 1982; Hinze and others, 1988; McKeown and Diehl, 1994). This provides at least a zone of weakness from which earthquakes can be triggered, but does not address how these faults are loaded.

Other models are based on rheological heterogeneity (slide 3). A weak lower crust/upper mantle can focus regional stresses and concentrate them in the upper crust (Liu and Zoback, 1997; Kenner and Segall, 2000; Grollimund and Zoback, 2001; Pollitz and others, 2001), though there does not appear to be higher heat flow or other heterogeneity in tectonic conditions that would explain a localized viscoelastic zone of weakness. A lower crustal detachment fault can help to localize deformation (Stuart and others, 1997), though no such fault has been indicated by seismic or geologic observations. A contrast in elastic moduli between the Reelfoot rift and the Missouri batholith can cause the regional stress field to concentrate shear stress in the intersection zone (Long, 1976; Campbell, 1978; Hildenbrand, 1985), except that there is no contemporary strain rate field to load this region.

Still others offer explanations based on loading heterogeneity (slide 4). Sinking of a high density rift pillow (Grana and Richardson, 1996; Pollitz and others, 2001), deglaciation of the Laurentide ice sheet (Wu and Johnston, 2000; Grollimund and Zoback, 2001; Pollitz and others, 2001), isostatic response to sediment unloading (Calais and others, 2010) and dynamic topography from mantle convection (Forte and others, 2007) could all play a role. A loading heterogeneity offers the best explanation for reactivation of the Reelfoot rift, but such models must also be consistent with the absence of a contemporary strain rate field. This provides a means by which to test these loading hypotheses, as discussed below.

\section{Models}

\section{Sinking Rift Pillow}

Observations of refraction data suggest a high-density rift pillow beneath the NMSZ (slide 5). Modeling of a sinking rift pillow over 100 ka shows that the process would lead to the development of a localized stress field within the Reelfoot rift that could explain New Madrid seismicity (Grana and Richardson, 1996). However, such a model does not provide a means to understand why seismicity has been active over the past several thousand years.

To address this timing issue, Pollitz and others (2001) proposed that sinking began several thousand years ago when the lower crust was suddenly weakened (slide 6 ). They suggest that either a thermal (from shear heating) or pressure perturbation (pressure-release melting) related to the last North American deglaciation led to a sudden weakening of the lower crust. 
Assuming that the latest cycle began in 1812, finite element models predict that present-day surface deformation should be characterized by horizontal motion directed radially toward the center of the step-over zone at a rate reaching $1.5 \mathrm{~mm} / \mathrm{yr}$ about $20 \mathrm{~km}$ from the center (slide 7). This corresponds to strain rates of $\sim 7.5 \times 10^{-8} \mathrm{yr}^{-1}$, which is about an order of magnitude larger than what is observed with contemporary GPS. This lack of an observable strain rate is problematic for sinking rift pillows.

Detachment Fault

In the detachment model of Stuart and others (slide 8; 1997), they state, "The model contains a subhorizontal detachment fault which is assumed to be near the domed top surface of locally thickened anomalous lower crust ("rift pillow"). Regional horizontal compression induces slip on the fault, and the slip creates a stress concentration in the upper crust above the rift pillow dome." However, model predicted rates of horizontal strain at the ground surface are about $10^{-7} \mathrm{yr}^{-1}$, two orders of magnitude greater than what is observed.

\section{Weak Zone}

Lui and Zoback (1997) postulate a weak zone (slide 9) and state, "Within the seismic zone, the heat flow appears to be slightly elevated $\left(\sim 60 \mathrm{~mW} / \mathrm{m}^{2}\right)$ relative to the background regional value of $45 \mathrm{~mW} / \mathrm{m}^{2}$... the lower crust and upper mantle are sufficiently weak within the seismic zone that intraplate stresses are largely transmitted through the upper crust (locally)..." But McKenna and others (slide 10; 2007) ask, "Is the New Madrid seismic zone hotter and weaker than its surroundings?" and state, "... reanalysis of the heat flow indicates that the anomaly is either absent or much smaller ( 3 rather than $15 \mathrm{~mW} / \mathrm{m}^{2}$ ) than assumed in the previous analyses, leading to much smaller ( $\sim 90$ percent) temperature anomalies and essentially the same lithospheric strength."

The most recent compilation (Blackwell and Richards, 2004) shows seven heat-flow measurements within the Reelfoot rift $\left(44,50,55,55,58,60\right.$, and $\left.65 \mathrm{~mW} \mathrm{~m}^{-2}\right)$, which yield a mean value of $55 \pm 7 \mathrm{~mW} \mathrm{~m}^{-2}$. The mean eastern U.S. heat flow is $52 \pm 22 \mathrm{~mW} \mathrm{~m}^{-2}$. For heat flows less than $62 \mathrm{~mW} \mathrm{~m}^{-2}$ and strain rates less than $10^{-9} \mathrm{yr}^{-1}$, lower crustal and upper mantle viscosities are greater than $10^{22} \mathrm{~Pa} \mathrm{~s}$ with a relaxation time greater than 10,000 years (slide 11). Such viscosities would not likely lead to the focusing of stresses within the Reelfoot rift since glacial retreat.

Kenner and Segall (2000; slide 12) appeal to a weak lower crust and state, "Relaxation of ...a weak lower crustal zone within an elastic lithosphere... after tectonic perturbations transfers stress to the overlying crust, generating a sequence of earthquakes that continues until the zone fully relaxes." They suggest that relaxation of the weak zone could have been induced by a loss of strength due to a thermal or fluid pressure perturbation, or by a transient change in regional stress. The model requires, however, that the viscosity of an infinitely long weak zone is instantaneously decreased to some finite value, which under uniform regional loading causes a localization of stress in the upper crust. After each earthquake, relaxation in the weak zone reloads the brittle part of the crust, eventually leading to another earthquake. In addition to obvious problems with an instantaneous change in viscous strength, lower crust relaxation itself is unable to reload a fault back to failure levels - a regional strain rate is required. Even without such regional loading, strain rates associated with lower crustal flow in the model are predicted to be as high as $5 \times 10^{-9} \mathrm{yr}^{-1}$ after each earthquake. Such rates are not currently observed. 
Unloading

Wu and Johnston (2000) considered deglaciation and earthquakes more broadly throughout North America (slide 13). They state, "It is found that glacial unloading is able to trigger paleo-earthquakes within the ice margin near Charlevoix and in Wabash Valley outside the ice margin. However, rebound stress decays away from the former ice margin, thus glacial unloading is unlikely to have triggered the large M8 earthquakes in New Madrid." Grollimund and Zoback (2001; slide 14), however, take an alternative view stating, "... modeling shows that the removal of the Laurentide ice sheet that covered large parts of the northern United States until ca. $20 \mathrm{ka}$ changed the stress field in the vicinity of New Madrid and caused seismic strain rates to increase by about three orders of magnitude." Their model, however, requires that the lithospheric mantle contain a zone with a viscosity one order of magnitude lower below the New Madrid seismic zone. As discussed in the earlier studies, there are no indicators with respect to temperature or other heterogeneities that would explain such a weak zone.

Calais and others (2010) examine the effect of river incision on the local stress field and thus triggering of New Madrid earthquakes (slide 15). They state, "We show that the upward flexure of the lithosphere caused by unloading from river incision between 16,000 and 10,000 years ago caused a reduction of normal stresses in the upper crust sufficient to unclamp preexisting faults close to failure equilibrium." This leads to surface strain rates of up to $10^{-9} \mathrm{yr}^{-1}$ beginning about 10,000 ka, which have steadily decreased to the present day (slide 16). As such unclamping stress changes are relatively small, this theory requires that the Reelfoot rift faults have been maintained in a state of near failure due to broad tectonic loading throughout North America.

\section{Mantle Geodynamics}

Forte and others (2007) model the geodynamics of the mantle to estimate stresses acting on the lithosphere (slide 17). In particular, they find "...using viscous flow models based on high resolution seismic tomography, that the descent of the ancient Farallon slab into the deep mantle beneath central North America induces a highly localized flow directly below the New Madrid seismic zone." Dynamic topography in the New Madrid region is depressed by more than $1 \mathrm{~km}$. The horizontal projection of the traction vector is several MPa in the vicinity of the NMSZ (slide 18). Surface strain rates have yet to be estimated based on this model.

\section{Conclusions}

Where does the modeling go from here? We think we know that the regional strain rate is less than or equal to $10^{-9} \mathrm{yr}^{-1}$, New Madrid seismicity likely represents the focusing of regional stresses on preexisting faults within the Reelfoot rift, and the most recent onset of seismicity appears to be associated with retreat of the Laurentide ice sheet: either loading increase or strength reduction due to deglaciation, or both. If there is a strength reduction, then New Madrid earthquakes likely represent stress release from a large reservoir of stress associated with continent building.

To further quantify the surface strain rates, should we rerun rift pillow sinking and large reservoir unloading models with rheologies consistent with low surface strain rates? Is there a heat flow anomaly in the New Madrid seismic zone? How can glacial retreat cause a weakening of the lower crust or upper mantle? How can glacial retreat cause a weakening of the Reelfoot rift faults? Can you have an earthquake cycle in an elastic medium with a stress boundary condition (as opposed to a velocity boundary condition)? This last question is one of the least 
studied, but perhaps holds the most promise to understand intraplate earthquakes where plates can be held in a long-term stress field, but strain rates are negligible.

\section{Presentation: Understanding midcontinent earthquakes: some challenges by Mian Liu}

\section{Introduction}

Some of the challenges of understanding midcontinent earthquakes include the following: How does stress evolve following large earthquakes in midcontinents? If it is a slow restoration, then what causes clustered earthquakes and how long can they continue? Midcontinent earthquakes may have long sequences of aftershocks. If so, can today's small earthquakes tell where the big ones will occur in the future? Is there a timescale-dependent spatial pattern of seismicity? Do migrating earthquakes in north China provide a different way to look at midcontinent earthquakes?

\section{Stress Evolution}

Li and others (2005) calculated the stress evolution following the 1811-1812 earthquakes (slide 3 ). They calculated the coulomb stress change by the 1811-1812 events and suggested that many moderate-sized earthquakes in the region since 1812 occurred in areas of elevated coulomb stress. Further, with the typical tectonic loading rates in midcontinents, it takes thousands of years, or more, to recover stress in the fault zone after a large earthquake (slide 4). Hence, without additional loading or fault weakening, producing M7+ earthquakes every 500 years in midcontinents is not expected. One way to have clustered earthquakes with periods of 500-year recurrence intervals is with fault weakening (slide 5). The greater and more steady the weakening, the shorter will be the recurrence intervals of earthquakes on the fault.

\section{Aftershocks}

Observations from Tangshan, China, indicate that aftershocks can continue for decades after a midcontinent earthquake (slide 6). Stein and Liu (2009) recently published results indicating that earthquakes in the New Madrid seismic zone could be aftershocks from the 18111812 earthquakes. There are many examples of long aftershock sequences in midcontinents (slide 7). Long aftershock sequences in midcontinents are predicted from the rate-and-state frictional law (Dieterich, 1994) and low stressing rates or from viscous relaxation, which shifts some stress from lower crust and upper mantle back to the upper crust. The high viscosities present in the midcontinental lower crust and upper mantle cause slower stress shifting.

\section{Spatiotemporal Complexity}

Another intriguing aspect of midcontinent earthquakes is their spatiotemporal complexity (Li and others, 2009). This complexity is illustrated in a simple viscoelastic model, started with a random stress perturbation (slide 8). The predicted distribution of seismicity varies considerably over different lengths of observation (slide 9). Over 100's of years, predicted seismicity shows both spatial clustering (in narrow belts) and scattering (across large regions). Over a longer period (1000's of years), predicted seismicity forms apparent "seismic belts," aligned with the regional orientations of maximum shear stress. Over an even longer period (10,000's of years), the predicted seismicity appears to be randomly scattered everywhere. Given that historic and 
instrumental records of earthquakes in the CEUS cover only a couple of hundred years, do we see the whole elephant (slide 10)?

Liu and others (2011) explore this problem and the difference between interplate and intraplate earthquakes using a relatively long record of earthquakes in northern China (slide 11). They noted that no large earthquakes have repeated on the same fault segment in the past 2000 years (slide 12). The epicenters of large earthquakes appear random and independent of the location of the previous large earthquake. There appears, however, to be a complementary moment release between major fault systems, indicating mechanical coupling between set of faults (slide 13).

\section{Conclusion}

In summary, for plate boundaries, faults are loaded rapidly at a constant rate by steady relative plate motion. Hence, earthquakes are spatially focused and temporally quasi-periodic, and the past is a good predictor of the future. In contrast, in midcontinents, tectonic loading is collectively accommodated by a complex system of interacting faults. The loading rate on a given fault is slow and may not be constant. Earthquakes can cluster on a fault for a while then shift to other faults. In this case, the past is a poor predictor of the future.

\section{Discussion and Recommendations}

\section{Campaign-style GPS measurements for the New Madrid seismic zone; How much will they improve the detection of deformation? by John Langbein}

Participants of the March 2011 Geodesy Workshop on the NMSZ recommended that campaign or survey mode GPS (SGPS) would be useful for augmenting the existing continuously operating GPS network (CGPS) and could improve our ability to detect deformation from any mechanism that drives repeated strain accumulation and sudden release in damaging earthquakes in the New Madrid region. To quantify the degree to which SGPS measurements can add improvement to signal detection, I have examined two different SGPS networks and two different models of strain accumulation in the NMSZ.

The first model examines the possibility of localized deformation due to deep slip within the NMSZ. For this model, I have set-up a 3-fault system illustrated in figure 5. These modeled faults are constrained to coincide with the recent (post-1994) seismicity obtained from the CERI earthquake catalog. The assumption is that these modeled faults are currently creeping at depth and they are loading the crust above. Eventually, the stress from creep at depth breaks the three fault planes above the creeping zones in a series of M7 earthquakes with an inter-event time of 500 years. Conceptually, this is similar to the model used by Frankel and others (2012) to explain the deformation that they detect from the current set of CGPS data. One difference, however, is that I'm using two more faults than the Reelfoot fault implemented by Frankel and others. These two additional NE trending faults are modeled as vertical, strike-slip faults; the southern fault is identified as the Cottonwood Grove fault and the northern fault is roughly aligned with the trend in seismicity.

The second model of fault-slip is simply a 1-dimensional, infinitely long screw dislocation that is allowed to slip below $12 \mathrm{~km}$ and tests the possibility of broad-scale, regional strain accumulation. Although not illustrated in figure 5, this modeled fault is centered on the 
Reelfoot fault and is oriented N45E, consistent with the overall trend of seismicity in the region and is similar to the fault model used by Newman and others (1999), and Newman (2000).

NMSZ GPS sites

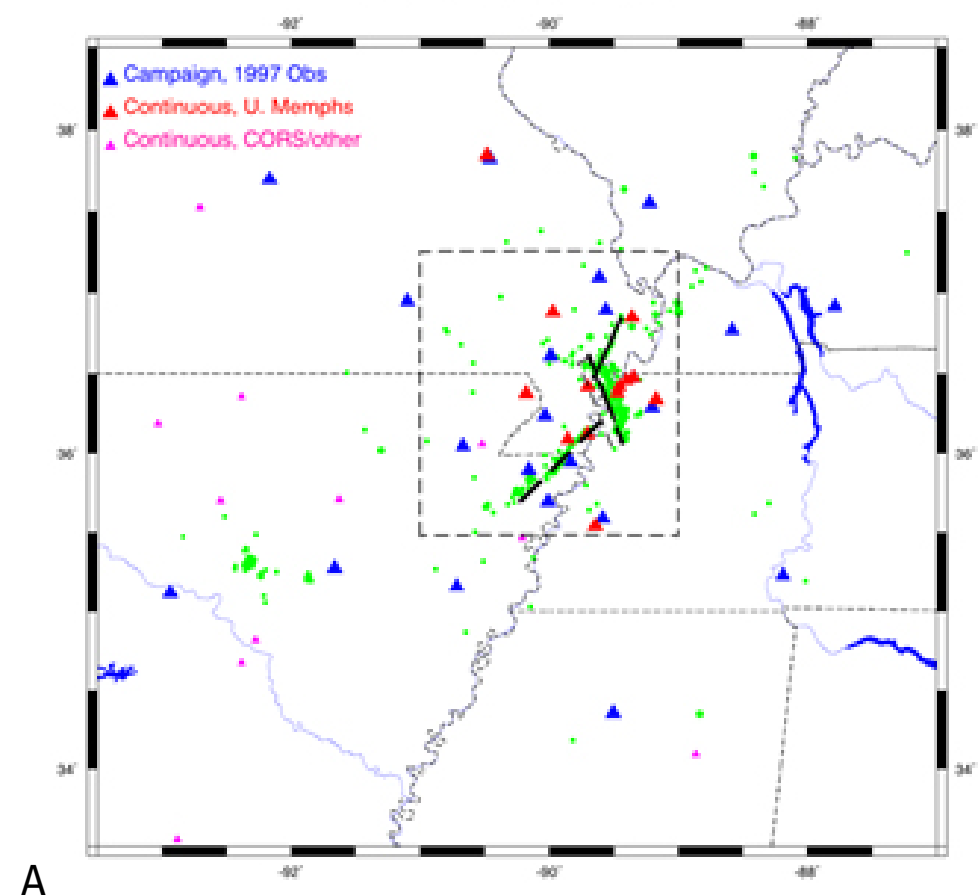

NMSZ GPS sites

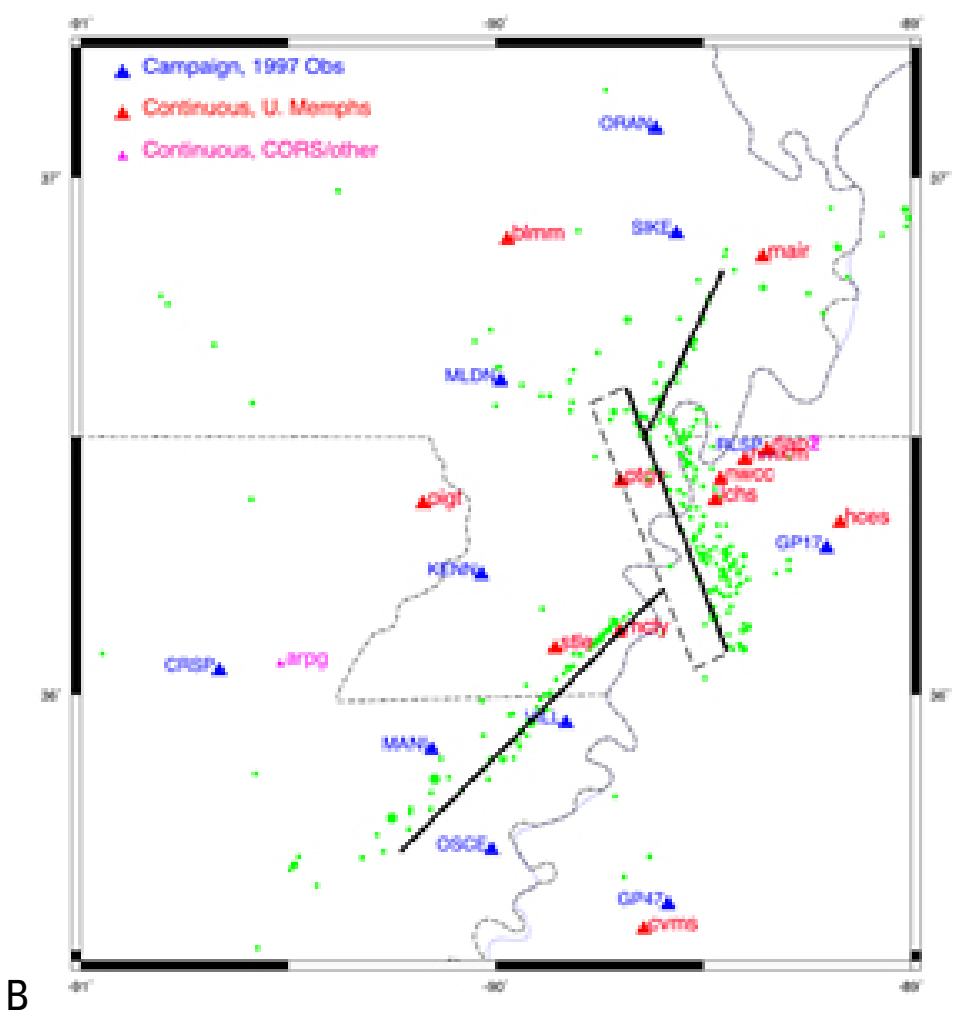

Figure 5. New Madrid GPS sites depicted on regional (A) and local (B) scales. 
I examine two different SGPS networks to test whether they can improve upon our estimates of deformation in the NMSZ. The first network is a suite of GPS monuments last measured in 1997 by Andy Newman and Seth Stein's group (fig. 5) (Newman, 2000). The second network is hypothetical and attempts to improve the detection of creep at depth relative to the existing CGPS network. Key to testing these SGPS networks is the noise model used to describe the errors in both the SGPS and the CGPS data. Although there is some ambiguity with respect to characterizing the long-period noise in the CGPS observation, characterizing the noise in campaign measurements boils down to an "educated guess."

As a basis to compare using SGPS data with the current, CGPS data, I use the velocities and their uncertainties that I estimated from the CGPS data, which are discussed in the Appendix. The key ingredient obtained from examination of the current set of CGPS measurements is an estimate of the random-walk noise and the velocities for each site relative to the 2005 International Terrestrial Reference Frame (ITRF2005).

Table 1. Sensitivity of SGPS and CGPS to creep at depth in NMSZ-Figure 5 SGPS network

\begin{tabular}{l|c|c|}
\cline { 2 - 3 } & $\begin{array}{c}\text { Existing CGPS data; 2000-2011 } \\
\text { Estimate and uncertainty }\end{array}$ & $\begin{array}{c}\text { CGPS (2000_2011) and hypothetical } \\
\text { SGPS (1997-2011) } \\
\text { Uncertainty ONLY }\end{array}$ \\
\hline \multirow{3}{*}{ Reelfoot, thrust } & Slip, mm/yr & Slip, mm/yr \\
Cottonwood Grove, right lateral & $2.74 \pm 3.13$ & 2.98 \\
"Northern" fault, right lateral & $-0.30 \pm 5.05$ & 4.26 \\
Long shear-zone (screw dislocation) & $4.68 \pm 7.92$ & 6.06 \\
\cline { 2 - 3 } & $1.29 \pm 3.24$ & 2.87 \\
\cline { 2 - 3 } Network translation, east & \multicolumn{2}{|c|}{ Nuisance Parameters (mm/yr) } \\
Network translation, north & $-13.60 \pm 0.13$ & 0.12 \\
Network translation, up & $0.53 \pm 0.15$ & 0.12 \\
Network rotation (nano-rad./yr) & $-0.56 \pm 0.11$ & 0.11 \\
& $3.83 \pm 1.68$ & 0.91
\end{tabular}

\section{Network 1}

As a basis to examine the utility of reoccupying the 23-station network last observed in 1997 by Newman (2000), I first use the existing CGPS data to estimate deep creep on the three hypothesized faults. I use my estimates of velocities and their uncertainties for both the horizontal and vertical components. Note that the estimated random-walk noise for the vertical (Appendix 1-table 1) is probably too low. Using these data and the fault geometry described in figure 5, I obtained the results shown in table 1 listed under CGPS data. Because the observations are referenced to ITRF2005, the largest signal is the translation and the rotation needed to transform the data into a local coordinate system defined by deep slip on the three faults. None of the estimated values of deep slip exceed their uncertainties. The estimated value of thrust on the Reelfoot fault is consistent with a low-level of creep loading the upper crust and rupturing at 500-year intervals in M7 earthquakes. The smaller uncertainty for the Reelfoot fault relative to the other two faults is driven by the numerous CGPS sites located in close proximity to this fault. 
Adding the hypothetical data from the 23 SGPS sites decreases the uncertainties slightly; at most by 23 percent for the two right-lateral faults. Here, I've assumed that the SGPS noise model is composed of $3 \mathrm{~mm} / \mathrm{yr}^{0.50}$ random-walk noise, 2 and $6 \mathrm{~mm} / \mathrm{yr}^{0.25}$ of flicker for horizontal and vertical respectively, and 2 and $4 \mathrm{~mm}$ of white noise for horizontal and vertical, respectively. It is also assumed that there were three observations both in 1997 and 2011. Although I specify both the flicker and white noise components for the SGPS network, the key parameter needed to characterize the rate uncertainty is the random-walk term. As stated above, this is a guess, but certainly it should be more than the random-walk associated with CGPS because the monuments used in the campaign GPS tend to be shallow. Re-measuring the SGPS network provides a very small (5 percent) improvement for resolving slip at depth for the Reelfoot fault because the CGPS network is concentrated nearby. On the other hand, the widely distributed SGPS network does improve the sensitivity of slip at depth for the two strike-slip faults (20 percent). Decreasing the assumed random walk from 3 to $2 \mathrm{~mm} / \mathrm{yr}^{0.50}$ makes only another 12 percent improvement in uncertainty estimates for deep slip.

For the second slip model of a screw dislocation at depth, the improvement in sensitivity due to the additional SGPS network is similar to the first model; a 14 percent decrease in uncertainty for the parameter representing slip at depth.

\section{Network 2}

From the March workshop, it was suggested that additional GPS coverage be implemented using standard, GPS campaign-style with the measurements separated by a decade. In this spirit, I have examined the possible improvements for measuring slip at depth with some hypothetical networks (figs. 6 and 7). It has been proposed that monuments for this campaignstyle GPS network be installed in clusters with monument spacing being much less than 100 meters (Agnew, 2007). By clustering the monuments, it is believed that the combined position estimates derived from the GPS data from each cluster will reduce the random-walk component of noise that is inherent to each individual monument.

As I did for the possible reoccupation with the Newman/Stein network, I test two models of slip (table 2). Because all of the measurements will be future measurements, I am using a slightly different noise model for the CGPS sites; instead of using the estimated values of white, flicker, and random-walk for each site, I will use "generic" values of noise closer to those listed as medians in Appendix 1-table 1; for horizontal, white is $0.9 \mathrm{~mm}$, flicker is $2 \mathrm{~mm} / \mathrm{yr}^{0.25}$, and random-walk is $1 \mathrm{~mm} / \mathrm{yr}^{0.5}$; and for vertical, white is $2.0 \mathrm{~mm}$, flicker is $6 \mathrm{~mm} / \mathrm{yr}^{0.25}$, and randomwalk is $2 \mathrm{~mm} / \mathrm{yr}^{0.5}$. For each SGPS observation, I am using the same noise model that I used in the first scenario. Justification for using a "generic" noise model is that the site-by-site models inferred from the current data are preliminary estimates and that future estimates could yield larger values of the random-walk as that parameter becomes better resolved with the longer timeseries. On the other hand, the short-term precision, the white noise component, used for the SGPS data can be reduced from 2 to $1 \mathrm{~mm}$ if the antennas used in these surveys are mechanically "forced" centered onto each monument. In practice, however, the random-walk component dominates the uncertainty for surveys that span intervals in excess of a few years.

Clustering for the examples presented below will have an assumed effect of reducing the random-walk contribution by $\mathrm{N}^{-0.5}$, where $\mathrm{N}$ is the number of monuments that form the cluster. The key assumption is that the random motions of each monument within the cluster are independent of the motion of the neighboring monument; if there is spatial dependence, then the $\sqrt{N}$ improvement would be weaker. 
Ideally, clustering of monuments would have the advantage of the Wyatt-Agnew deep drill-braced monuments without the high cost of construction. Like the braced monument with its 4 to 5 legs, the multiple monuments of the cluster sample different parts of the near-surface material and tend to average out the variations of movement between the different legs or monuments. Logistically, once the cluster of monuments are installed, only a single observer is needed to set-up multiple GPS receivers and antennas on each monument within the cluster and to monitor the equipment during the observing session.

Currently, there exists approximately 10 years of observations with the existing CGPS network. Assuming that a new SGPS network is constructed and observed now (2011), and remeasured in 10 years, then the future dataset will consists of 20 years of CGPS and 10 years of SGPS measurements.

Table 2 lists the results of estimating sensitivity for creep at depth for the three faults using the network configuration in figure 6 . The first two columns of slip sensitivities provide the basis to judge the improvement in sensitivity from additional SGPS. These two columns represent the sensitivity of the existing CGPS network to creep at depth. By waiting 10 years, the sensitivity to slip is improved by a factor of $\sqrt{2}$.

As a possible goal for the new SGPS network, it should provide an $\sqrt{2}$ improvement over simply letting the CGPS network collect an additional 10 years of data. Equivalently, this target would represent 40 years of CGPS data or, equivalently, 20 years of CGPS data along with 10years of data from a hypothetical, SGPS network. 

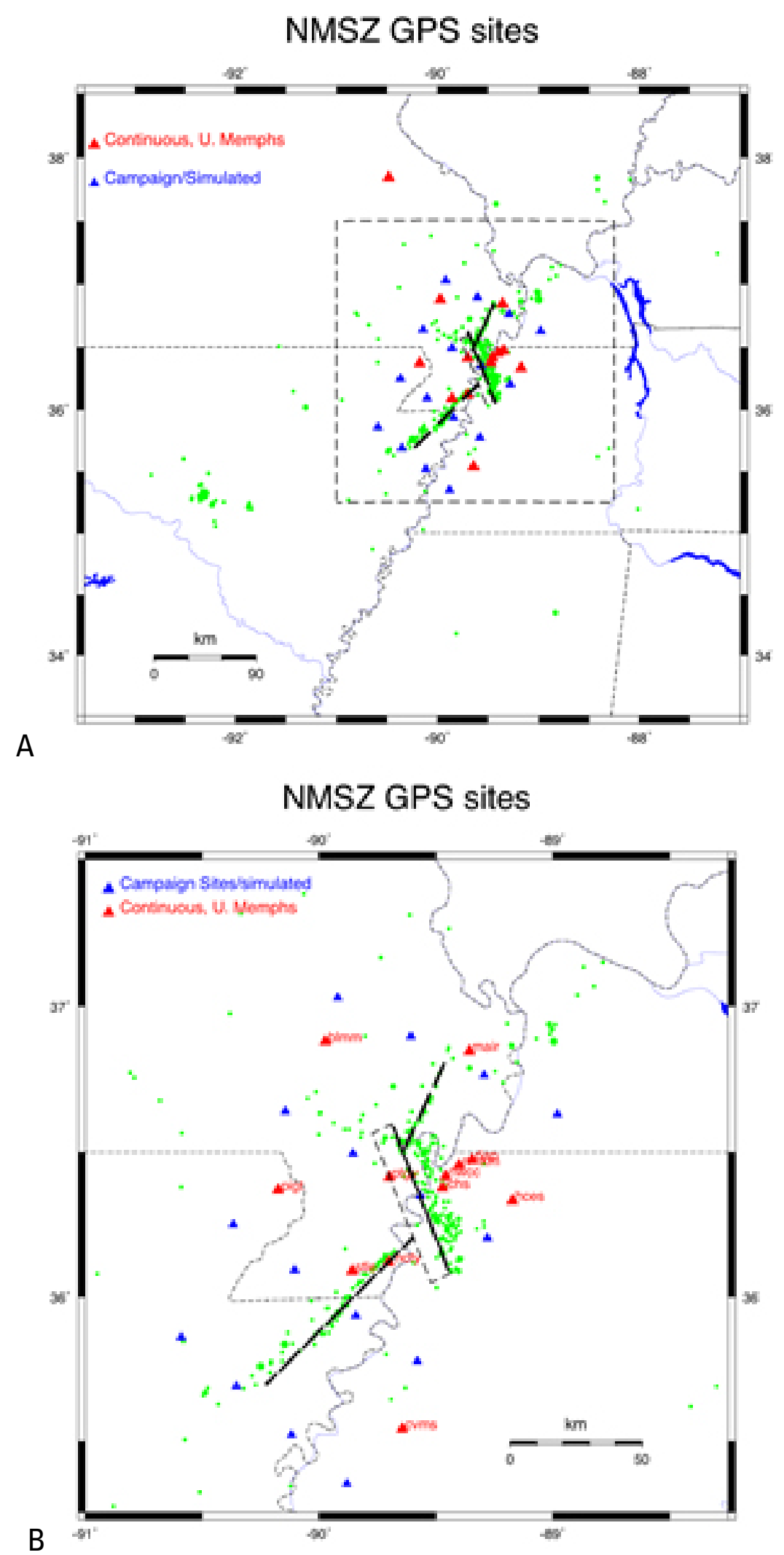

Figure 6. Simulated campaign sites at regional $(A)$ and local $(B)$ scales. 
The remaining columns in table 2 show how combinations of SGPS and CGPS networks can affect the sensitivities to slip at depth. The column label 16-SGPS consisting of single monuments distributed as shown in figure 6 improves the sensitivities by only a few percent ( 5 percent) relative to simply using 20 years of CGPS data. Increasing the clustering from 1 to 3 provides additional improvement (11 percent). In particular, using the SGPS network improves the slip-sensitivities for both of the right-lateral faults. Adding more monuments to each cluster, from 3 to 10 further improves the precision of the SGPS data and provides improved sensitivity. As an alternative to 16 clusters of 3 monuments of SGPS, a 49-monument network ( 7 by 7 ) spanning the same area depicted in figure 6 provides similar performance as clusters of 3 monuments.

Results for the second model of a screw dislocation are similar to those of the first model using three faults.

Table 2. Sensitivity of SGPS and CGPS to creep at depth in NMSZ; Future measurements as outlined in figure 6.

\begin{tabular}{|c|c|c|c|c|c|c|c|c|c|c|}
\hline \multicolumn{11}{|c|}{ Estimated uncertainties in slip rate from creep at depth; $\mathbf{m m} / \mathbf{y r}$} \\
\hline & \multicolumn{2}{|c|}{$\begin{array}{l}\text { CGPS data } \\
\text { only; existing } \\
\text { network }\end{array}$} & \multirow{2}{*}{$\begin{array}{c}\text { Target for } \\
\text { CGPS and } \\
\text { SGPS } \\
\sqrt{2} \\
\begin{array}{c}\text { improve- } \\
\text { ment }\end{array}\end{array}$} & \multicolumn{7}{|c|}{ Combination CGPS (20 years), and SGPS (10 years) } \\
\hline & \begin{tabular}{|c|}
10 \\
years
\end{tabular} & $\begin{array}{c}20 \\
\text { years }\end{array}$ & & 16 SGPS & 16 SGPS & 16 SGPS & 49 SGPS & 36 SGPS & 49 & SGPS \\
\hline N-Cluster & -- & -- & - & 1 & 3 & 10 & 1 & 3 & & 3 \\
\hline Reelfoot thrust & 3.57 & 2.45 & 1.73 & 2.38 & 2.22 & 1.88 & 2.13 & 1.77 & & 1.74 \\
\hline $\begin{array}{l}\text { Cottonwood } \\
\text { Grove, RL }\end{array}$ & 3.73 & 2.60 & 1.84 & 2.46 & 2.25 & 1.83 & 2.23 & 1.97 & & 1.84 \\
\hline Northern, RL & 6.95 & 4.84 & 3.43 & 4.68 & 4.40 & 3.75 & 4.42 & 3.91 & & 3.84 \\
\hline $\begin{array}{l}\text { Shear zone- } \\
\text { screw } \\
\text { dislocation }\end{array}$ & 2.85 & 1.99 & 1.41 & 1.91 & 1.78 & 1.47 & 1.81 & 1.64 & & 1.56 \\
\hline
\end{tabular}

As an alternative to networks that have equally spaced monuments, figure 7 and table 3 show the sensitivity to slip from three linear, but densely spaced SGPS monuments that span the NMSZ. Each linear array has monument spacing that is roughly optimized to estimate both the amount of slip at depth and the locking depth using the guidance provided by Johnson (1993). With 3 arrays of 12 monument clusters each, this network has similar sensitivity as the 36monument cluster, uniformly spaced network (table 2). 


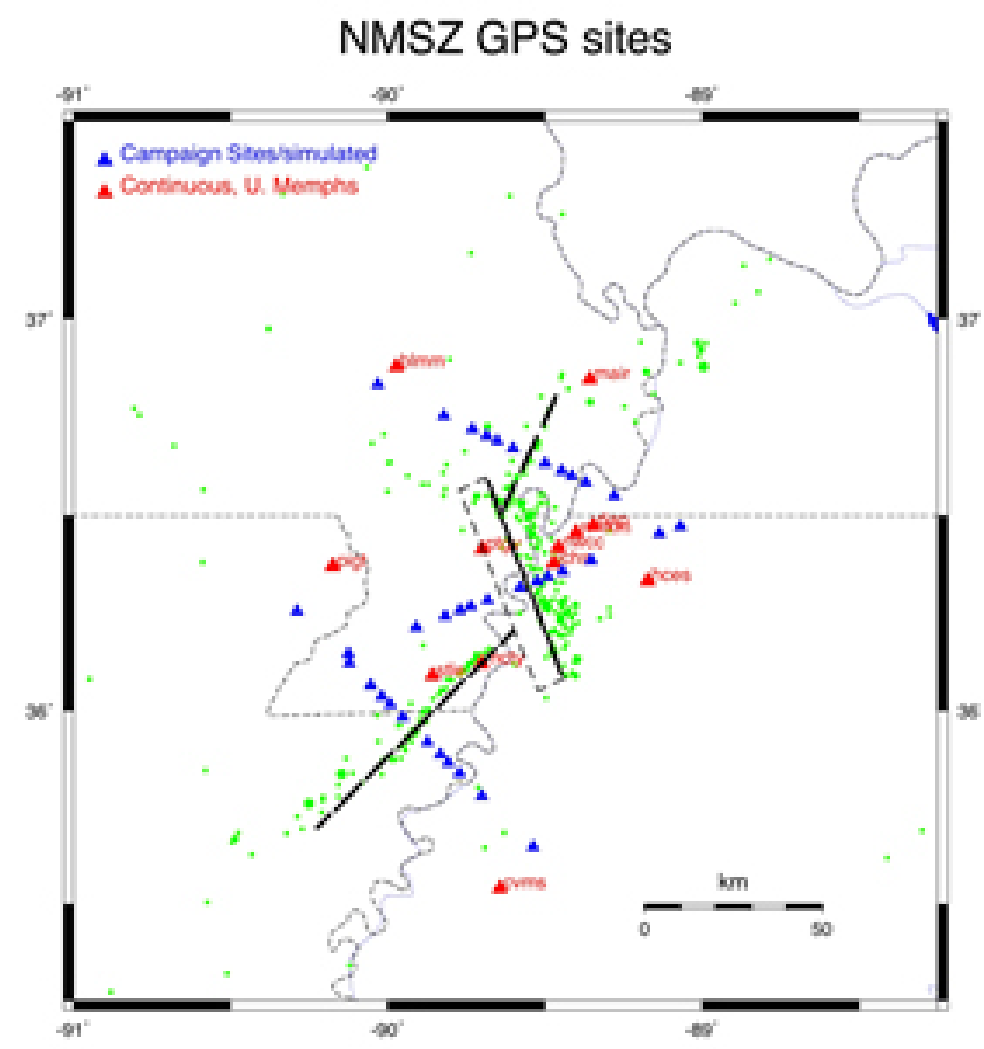

Figure 7. Same as figure $6 B$ but showing three linear SGPS networks spanning the NMSZ with monument spacing clustered at $12 \mathrm{~km}$ from fault to optimize resolution of locking depth (Langbein, 2008).

If the goal of the SGPS network is to reduce the composite uncertainty by a factor of $\sqrt{2}$ relative to 20 years of CGPS measurements ( $4^{\text {th }}$ column, table 2$)$, then using one of the two network configurations listed in the last columns of table 2 will achieve that goal or 3 linear arrays of 12 monument clusters spanning each fault (table 3 ). These networks would achieve the same sensitivity as 40 years of CGPS measurements but in 20 years.

\section{Limitations}

This study only focuses on the goal of detection of crustal deformation from an assumed source of deformation. A broader study would incorporate formal resolution analysis. However, given the current observation that the deformation of the NMSZ has a very low signal to noise, with a ratio of less than one, the proposed networks are not necessarily optimized to provide secondary information such as the "locking depth" or the distribution of slip at depth. If the creep rate at depth is of the order of $2 \mathrm{~mm} / \mathrm{yr}$, then the slip rate is equal to the rate uncertainty, even with SGPS data complementing the CGPS data (tables 1-3). None of the proposed networks are able to reduce the uncertainty in slip rate to less than $1 \mathrm{~mm} / \mathrm{yr}$ with observations that span the next decade. 
Table 3. Sensitivity of SGPS and CGPS to creep at depth in the NMSZ; Future measurements as outlined in figure 7.

\begin{tabular}{|c|c|c|c|c|c|c|c|}
\hline \multicolumn{8}{|c|}{ Estimated uncertainties in slip rate from creep at depth; $\mathbf{m m} / \mathbf{y r}$} \\
\hline & \multicolumn{2}{|c|}{$\begin{array}{l}\text { CGPS data only; } \\
\text { existing network }\end{array}$} & \multirow{2}{*}{$\begin{array}{c}\text { Target for } \\
\text { CGPS and } \\
\text { SGP } \\
\sqrt{2} \\
\text { improve- } \\
\text { ment }\end{array}$} & \multicolumn{4}{|c|}{$\begin{array}{c}\text { Combination CGPS (20 years), and SGPS } \\
\text { (10-years) } \\
\text { Each cluster with } 3 \text { monuments }\end{array}$} \\
\hline & 10 years & 20 years & & 27 SGPS & 36 SGPS & 45 SGPS & 60 SGPS \\
\hline Reelfoot thrust & 3.57 & 2.45 & 1.73 & 1.93 & 1.76 & 1.67 & 1.48 \\
\hline $\begin{array}{l}\text { Cottonwood Grove, } \\
\text { RL }\end{array}$ & 3.73 & 2.60 & 1.84 & 1.94 & 1.81 & 1.73 & 1.56 \\
\hline Northern, RL & 6.95 & 4.84 & 3.43 & 3.95 & 3.61 & 3.63 & 3.12 \\
\hline $\begin{array}{l}\text { Shear zone, screw } \\
\text { dislocation }\end{array}$ & 2.85 & 1.99 & 1.41 & 1.66 & 1.61 & 1.51 & 1.42 \\
\hline
\end{tabular}

With respect to obtaining better constraints for creep at depth, the linear arrays shown in figure 7 should be sufficient assuming that the signal to noise becomes large enough to warrant additional data analysis. Analyses by Johnson (1993), Johnson and Wyatt (1994), and Blewitt (2000) all suggest that having monuments installed at distances roughly one locking-depth away plus the "far-field" from the surface projection of strike-slip faults should be the optimal network configurations for resolving both the magnitude of slip and the locking depth. The analyses by Johnson (1993) and Johnson and Wyatt (1994) suggest that, once the number of sites that span a fault exceeds 10 or so, increasing the number of sites is not necessarily warranted.

On the other hand, to simply detect slip, one only needs to install sites where one expects to see the maximum displacement. For instance, the cluster of CGPS sites installed by CERI located east of the seismicity trend of the Reelfoot fault is within the zone of maximum displacement from this thrust fault; assuming that it is creeping at depth. Consequently, a spatially diffuse network of SGPS sites only provides marginal improvement of the sensitivity to slip from the Reelfoot fault unless more SGPS sites are installed where the displacement is expected to be the highest.

Because of the lack of CGPS sites located in the zone of maximum displacements for possible slip at depth from both the Cottonwood Grove and the northern faults, SGPS measurements can improve the detection of hypothesized creep from these faults. Expansion of the CGPS network in the areas near these two faults is warranted.

\section{Conclusions}

Re-measuring the Newman/Stein network could improve our sensitivity of creep at depth by about 20 percent if this network is measured now. This improvement is true only for the potential fault zones located north and south of the Reelfoot fault. With the current dense distribution of CGPS near the Reelfoot, the sparse Newman/Stein network does not provide any significant information for that fault. Finally, assuming the rate uncertainty is improved by $\sqrt{\text { time }}$, then the 20 percent reduction in sensitivity provided by SGPS represents an additional 5 years of observations from the existing CGPS network. 
By carefully designing a SGPS network that spans each of the potential faults in the NMSZ, it is possible over the next 10 years to achieve the same sensitivity to creep at depth if we simply continue to operate the existing CGPS network for another 30 years. The key assumption is that the SGPS network be built with clusters of monuments and, most importantly, that random motions of the monuments that form each cluster are statistically independent.

On the other hand, even with 10 years of data from a new SGPS network, the estimated rate uncertainty for slip at depth is roughly the same size as the anticipated slip rate of $2 \mathrm{~mm} / \mathrm{yr}$. The signal to noise ratio is one. Given the potentially small signals due to creep at depth (or from any other mechanism), none of the proposed networks operating over the next decade will provide much insight into the mechanics of deformation in the NMSZ.

If possible, additional CGPS stations should be installed that better span both the Cottonwood Grove and northern faults. The locations of these sites should be targeted at places where deformation could be highest; new sites should be located roughly one locking depth from the fault. Perhaps, by working with local and state transportation departments and surveyors, these groups could be encouraged to install monuments that extend to several 10's of meters depth and are isolated from the surface materials. Financial incentives or cost sharing might work here.

\section{Appendix 1: Noise models and data processing}

As a basis to compare the use of SGPS data with the current, CGPS data, I use only the velocities and their uncertainties that I estimated from the CGPS data. Here, I use the GIPSY determined position estimates in an ITRF2005 reference frame. Common-mode signals were removed by de-trending time series of displacements, and averaging the residuals from 8 of the better behaved NMSZ CGPS stations. I used the computer program developed by me (Langbein, 2004, 2008) to estimate the east, north, and vertical displacement rates and the parameters of a noise model; offsets, if detected, were also estimated. The noise model (table A1.1) consists of three components; white noise, flicker noise, and random-walk noise consistent with the noise characteristics found for other regional GPS networks. Although a power-law noise is indistinguishable from the flicker/random-walk model (Langbein, 2008), I opted to use the flicker/random-walk model because I believe it is physically justifiable and, due to the randomwalk component at the long periods, it provides a conservative estimate of uncertainty for rate. Physically, the flicker component represents noise within the GPS system including receiver noise and software models that characterize the GPS path between receiver and satellite. The random-walk component characterizes monument "wobble"; this type of noise is seen with longbaseline strainmeters, borehole strainmeters, and other highly sensitive devices that measure deformation in the earth. Detecting and estimating the amplitude of random-walk noise robustly in the presence of flicker noise is difficult because the flicker component can obscure the random walk at the longest periods. Even if not necessarily detectable, small amounts of random walk will significantly impact the estimate of the rate uncertainty. Consequently, based upon my experience analyzing the GPS data from the SCIGN network, I constrained the noise model to have at least $0.5 \mathrm{~mm} / \mathrm{yr}^{0.5}$ of random-walk noise.

Comparison with the estimates of the noise parameters for the 12 sites of the NMSZ network and those obtained by Langbein (2008) for the SCIGN and southern Nevada GPS network indicates that the noise found in the NMSZ data is higher than that from southern 
California and Nevada. The causes are: 1) GIPSY point-positioning time series tend to be noisier than those from GAMIT produced time series; and 2) southern California and Nevada tend to be drier than the central U.S. Comparison of time series of position changes for the NMSZ-GPS data computed by E. Calais (http://web.ics.purdue.edu/ ecalais/projects/noam/nmsz/ts) using GAMIT have lower noise than similar time series obtained using GIPSY. The time series for southern California and Nevada networks evaluated by Langbein (2008) were obtained using GAMIT from the SOPAC website. Additional noise beyond the GIPSY/GAMIT difference for the New Madrid sites could be due to differences in climate and soil conditions. More active weather could contribute to variations in GPS path length, which may not be correctly modeled in the GPS processing software. In addition, the depth to bedrock tends to be deeper in the Mississippi Valley than elsewhere (for instance, Robert Smalley from the University of Memphis was able to pile-drive monuments to a $60-\mathrm{ft}$ depth, whereas, in many parts of California and Nevada, drilling, rather than auguring, was used to install braced monuments).

Table A1.1. Noise components from NMSZ GPS network. Data processed using GIPSY; inter-quartile range and median.

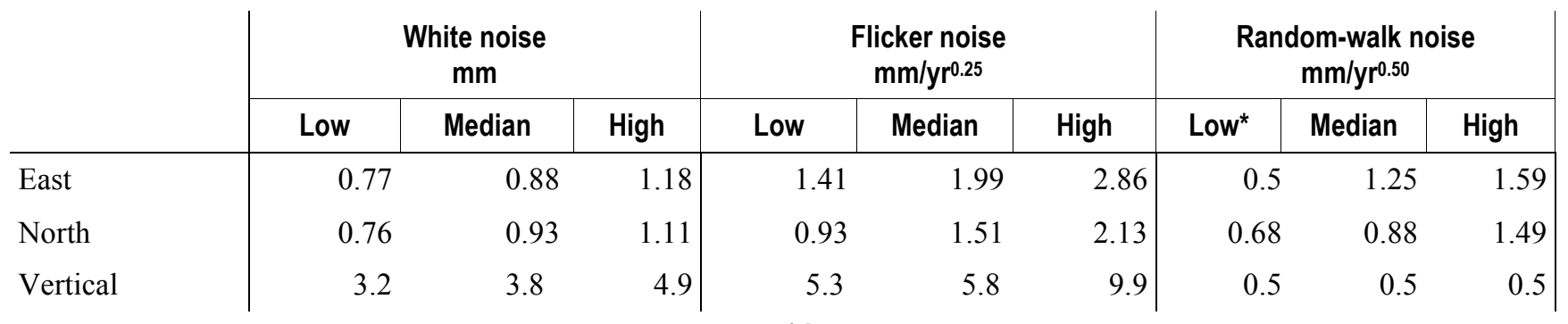

* Note - Random-walk noise constrained to exceed $0.5 \mathrm{~mm} / \mathrm{yr}^{0.5}$

\section{Appendix 2: Cost comparison of CGPS and SGPS}

SGPS

Install one cluster consisting of 3 monuments each day

Rental of compressor and jack hammer at \$50/day for breaker and $\$ 120 /$ day for compressors $\$ 200 /$ day

3 sections of 20' x 1" galvanized pipe; approximately $\$ 50$ per monument

$\$ 150$

Labor, 2 people/day at $\$ 25 / \mathrm{hr} /$ person

$\$ 400$

per diem for 2 people, $\$ 75 /$ day

$\$ 150$

motel for 2 people, $\$ 100$ each

$\$ 200$

Vehicle cost; guess $\$ 100 /$ day

$\$ 100$

misc. $\$ 25$

$\$ 25$

Observe single cluster-2 days, one person

$\$ 1,225$

Labor of 1 person at $\$ 30$ /hour for 10 hours over 2 days

$\$ 600$

per diem of $\$ 75 /$ day

$\$ 150$

motel for 1 person, $\$ 100 /$ day

$\$ 200$

Vehicle cost; guess \$100/day

$\$ 200$

misc. $\$ 25$

$\$ 25$

TOTAL operation per site/year: $\quad \$ 1,175$ 
Network of 36 clusters

Installation

$\$ 44,100$

2 observations $\$ 1075 \times 2 \times 36$

$\$ 77,400$

*Assumes that GPS equipment is either "owned" or borrowed for free

$\$ 121,500$

CGPS

UNAVCO price for installation for San Francisco Bay ARRA sites was $\$ 75 \mathrm{~K} /$ site with no receivers (USGS supplied the receivers) but UNAVCO did everything else including permitting, communication, etc. If one could do some of the tasks "in-house," an estimate of $\$ 25 \mathrm{~K} /$ site including the receiver could be achieved.

\section{Acknowledgments}

We thank the USGS for funding this productive workshop. We also thank Fred Pollitz and Yuehua Zeng for thoughtful and constrictive reviews of this report. Finally, we are grateful to the participants for vigorous discussion.

\section{Participants}

\begin{tabular}{|c|c|c|c|}
\hline Duncan & Agnew & University of California at San Diego & dagnew@ucsd.edu \\
\hline Mike & Blanpied & USGS & mblanpied@usgs.gov \\
\hline Oliver & Boyd & USGS & olboyd@usgs.gov \\
\hline Eric & Calais & Purdue University & ecalais@purdue.edu \\
\hline Alessandro & Forte & UQAM & forte60@gmail.com \\
\hline Art & Frankel & USGS & afrankel@usgs.gov \\
\hline Andy & Freed & Purdue University & freed@purdue.edu \\
\hline Michael & Hamburger & Indiana University & hamburg@indiana.edu \\
\hline Eric & Hetland & University of Michigan & ehetland@umich.edu \\
\hline Nancy & King & USGS & nking@usgs.gov \\
\hline John & Langbein & USGS & langbein@usgs.gov \\
\hline Mian & Liu & University of Missouri-Columbia & lium@missouri.edu \\
\hline Harold & Magistrale & FM Global & Harold.Magistrale@fmglobal.com \\
\hline Stephane & Mazzotti $^{1}$ & Geological Survey of Canada & smazzotti@nrcan.gc.ca \\
\hline Jill & McCarthy & USGS & jmccarthy@usgs.gov \\
\hline Jessica & Murray-Moraleda & USGS & jrmurray@usgs.gov \\
\hline Andy & Newman & Georgia Institute of Technology & anewman@gatech.edu \\
\hline Chris & Pearson & National Geodetic Survey & Chris.Pearson@noaa.gov \\
\hline Fred & Pollitz & USGS & fpollitz@usgs.gov \\
\hline Paul & Segall & Stanford University & segall@stanford.edu \\
\hline Bob & Smalley & University of Memphis & rsmalley@memphis.edu \\
\hline Seth & Stein & Northwestern & seth@earth.northwestern.edu \\
\hline Wayne & Thatcher & USGS & thatcher@usgs.gov \\
\hline John & Vidale & University of Washington & John_vidale@mac.com \\
\hline
\end{tabular}

${ }^{1}$ Due to travel difficulties, Stephane Mazzotti was unable to attend the meeting. 


$\begin{array}{llll}\text { Rob } & \text { Williams } & \text { USGS } & \text { rawilliams@usgs.gov } \\ \text { Yuehua } & \text { Zeng } & \text { USGS } & \text { zeng@usgs.gov } \\ \text { Mark } & \text { Zoback } & \text { Stanford University } & \text { zoback@stanford.edu }\end{array}$

\section{Software}

Herring, T.A., King, R.W., and McClusky, S.C., 2010; GLOBK reference manual-Global Kalman filter VLBI and GPS analysis program, release 10.4, 91 p., available at http://www-gpsg.mit.edu/ simon/gtgk/docs.htm.

Langbein, John, 2004, Noise in two-color electronic distance meter measurements revisited, Journal of Geophysical Research, v. 109, B04406, 16 p., doi:10.1029/2003JB002819; est_noise software available at ftp://ehzftp.wr.usgs.gov/langbein/est_noise.

Williams, S.D.P., 2008, CATS: GPS coordinate time series analysis software: GPS Solutions, v. 12, no. 2, 147-153, doi:10.1007/s10291-007-0086-4, available at http://www.springerlink.com/content/817j28u731647063/ http://www.pol.ac.uk/home/staff/? user=WillSimoCats.

\section{References}

Agnew, D.C., 2007, Geodetic measurements for urban earthquake hazard in San Diego, California: The Rose Canyon fault zone-Final Technical report for USGS grant 04HQGR0008: University of California, San Diego, Scripps Institution of Oceanography, La Jolla, Calif.

Angelier, Jacques, 1979, Determination of the mean principal directions of stresses for a given fault population: Tectonophysics, v. 56, no. 3-4, p. T17-T26.

Argus, D.F., and Gordon, R.G., 1996, Tests of the rigid-plate hypothesis and bounds on intraplate deformation using geodetic data from very long baseline interferometry: Journal of Geophysical Research, v. 101, no. B6, p. 13,555-13,572.

Blackwell, D.D., and Richards, Maria, 2004, Geothermal Map of North America: American Association of Petroleum Geologists, scale 1:6,500,000.

Blewitt, G., 2000, Geodetic network optimization for geophysical parameters: Geophysical Research Letters, v. 27, no. 22, p. 3615-3618.

Braile, L.W., Keller, G.R., Hinze, W.J., and Lidiak, E.G., 1982, An ancient rift complex and its relation to contemporary seismicity in the New Madrid seismic zone: Tectonics, v. 1, no. 225237.

Calais, Eric, Freed, A.M., Van Arsdale, R.B., and Stein, Seth, 2010, Triggering of New Madrid seismicity by late-Pleistocene erosion: Nature, v. 466, p. 608-611. 
Calais, Eric, Han, J.Y., DeMets, Charles, and Nocquet, J.M., 2006, Deformation of the North American plate interior from a decade of continuous GPS measurements: Journal of Geophysical Research, v. 111, no. B06402, 23 p. doi: 10.1029/2005JB004253.

Calais, Eric, Mattioli, G., DeMets, Charles, Nocquet, J.M., Stein, S., Newman, A., and Rydelek, P., 2005, Seismology: Tectonic strain in plate interiors?: Nature, v. 438, p. E9-E10.

Calais, Eric, and Stein, Seth, 2009, Time-variable deformation in the New Madrid seismic zone: Science, v. 323, no. 5920, p. 1442-1442.

Campbell, D.L., 1978, Investigation of the stress-concentration mechanism for intraplate earthquakes: Geophysical Research Letters, v. 5, no. 6, p. 477-479.

Cox, R.T., and Van Arsdale, R.B., 2002, The Mississippi Embayment, North America: A first order continental structure generated by the Cretaceous superplume mantle event: Journal of Geodynamics, v. 34, no. 2, p. 163-176.

Dieterich, J., 1994, A consitutive law for rate of earthquake production and its application to earthquake clustering: Journal of Geophysical Research, v. 99, no. B2, p. 2601-2618.

Forte, A.M., Mitrovica, J.X., Moucha, R., Simmons, N.A., and Grand, S.P., 2007, Descent of the ancient Farallon slab drives localized mantle flow below the New Madrid seismic zone: Geophysical Research Letters, v. 34, no. L04308, p. doi:10.1029/2006GL027895.

Frankel, Arthur, Smalley, Robert, and Paul, J., 2012, Significant motions between GPS sites in the New Madrid region: Implications for seismic hazard: Bulletin of the Seismological Society of America, v. 102, no. 2, p. 479-489.

Gan, Weijun, and Prescott, W.H., 2001, Crustal deformation rates in central and eastern U.S. inferred from GPS: Geophysical Research Letters, v. 28, no. 19, p. 3733-3736.

Gephart, J.W., 1985, Principal stress directions and the ambiguity in fault plane identification from focal mechanisms: Bulletin of the Seismological Society of America, v. 75, no. 621-625.

Grana, J.P., and Richardson, R.M., 1996, Tectonic stress within the New Madrid seismic zone: Journal of Geophysical Research, v. 101, no. B3, p. 5445-5458.

Grollimund, B., and Zoback, M.D., 2001, Did deglaciation trigger intraplate seismicity in the New Madrid seismic zone?: Geology, v. 29, no. 2, p. 175-178.

Hammond, W.C., and Thatcher, Wayne, 2007, Crustal deformation across the Sierra Nevada, northern Walker Lane, Basin and Range transition, western United States measured with GPS, 2000-2004: Journal of Geophysical Research, v. 112, no. B05411, 26 p., doi:10.1029/2006JB004625. 
Herring, T.A., 2003, MATLAB Tools for viewing GPS velocities and time series: GPS Solutions, v. 7, p. 194-199.

Herring, T.A., Gwinn, C.R., and Shapiro, I.I., 1986, Geodesy by radio interferometry: studies of the forced nutations of the earth: 1. Data analysis: Journal of Geophysical Research, v. 91(B5), p. 4745-4754.

Hildenbrand, T.G., 1985, Rift structure of the northern Mississippi embayment from analysis of gravity and magnetic data: Journal of Geophysical Research, v. 90, B14, p. 12,607-12,622, doi:10.1029/JB090iB14p12607.

Hinze, W.J., Braile, L.W., Keller, G.R., and Lidiak, E.G., 1988, Models for midcontinent tectonism: An update: Reviews of Geophysics, v. 26, no. 4, p. 699-717, doi:10.1029/RG026i004p00699.

Holbrook, John, Autin, W.J., Rittenour, T.M., Marshak, Stephen, and Goble, R.J., 2006, Stratigraphic evidence for millennial-scale temporal clustering of earthquakes on a continentalinterior fault: Holocene Mississippi River floodplain deposits, New Madrid seismic zone, USA: Tectonophysics, v. 420, p. 431-454.

Hurd, Owen, and Zoback, M.D., 2012, Regional stress orientations and slip compatibility of earthquake focal planes in the New Madrid seismic zone: Seismological Research Letters, v. 83, no. 4, p. 672-679, doi:10.1785/0220110122.

Johnson, H.O., 1993, Techniques and studies in crustal deformation, University of California at San Diego.

Johnson, H.O., and Wyatt, F.K., 1994, Geodetic network design for fault mechanics studies: Manuscripta Geodetica, v. 19, no. 309-323.

Kenner, S.J., and Segall, Paul, 2000, A mechanical model for intraplate earthquakes: application to the New Madrid seismic zone.: Science, v. 289, p. 2329-2332.

Langbein, John, 2004, Noise in two-color electronic distance meter measurements revisited: Journal of Geophysical Research, v. 109, no. B04406, 16 p., doi:10.1029/2003JB002819.

Langbein, John, 2008, Noise in GPS displacement measurements from Southern California and Southern Nevada: Journal of Geophysical Research, v. 113, no. B05405, 12 p., doi:10.1029/2007JB005247.

Langbein, John, 2012, Estimating rate uncertainty with maximum likelihood: differences between power-law and flicker-random-walk models: Journal of Geodesy, v. 86, no. 9, p. 775-783. 
Li, Qinqsong, Liu, Mian, and Sandvol, Eric, 2005, Stress evolution following the 1811-1812 large earthquakes in the New Madrid seismic zone: Geophysical Research Letters, v. 32, no. L11310, 4 p., doi:10.1029/2004GL022133.

Li, Qingsong, Liu, Mian, and Stein, Seth, 2009, Spatiotemporal complexity of continental intraplate seismicity: Insights from geodynamic modeling and implications for seismic hazard estimation: Bulletin of the Seismological Society of America, v. 99, no. 1, p. 52-60, doi: $10.1785 / 0120080005$.

Liu, Lanbo, and Zoback, M.D., 1997, Lithospheric strength and intraplate seismicity in the New Madrid seismic zone: Tectonics, v. 16, no. 4, p. 585-595.

Liu, Lanbo, Zoback, M.D., and Segall, Paul, 1992, Rapid intraplate strain accumulation in the New Madrid seismic zone: Science, v. 257, no. 5077, p. 1666-1669.

Liu, Mian, Stein, Seth, and Wang, Hui, 2011, 2000 years of migrating earthquakes in North China: How earthquakes in midcontinents differ from those at plate boundaries: Lithosphere, v. 3, no. 2, p. 128-132, doi: 10.1130/L129.1.

Long, L.T., 1976, Speculations concerning southeastern earthquakes, mafic intrusions, gravity anomalies, and stress amplification: Earthquake Notes, v. 47, no. 3, p. 29-35.

Marquez-Azua, Bertha, and DeMets, Charles, 2003, Crustal velocity field of Mexico from continuous GPS measurements, 1993 to June, 2001: Implications for the neotectonics of Mexico: Journal of Geophysical Research, v. 108, no. B9, 20 p.

Mattioli, G.S., and Jansma, P.E., 2007, Evaluation of monument stability and noise associated with campaign and continuous GPS geodesy in the New Madrid seismic zone and other areas of unconsolidated sediment: U.S. Geological Survey Final Technical Report, v. 02HQGR0107, $19 \mathrm{p}$.

Mazzotti, Stephane, and Townend, John, 2010, State of stress in central and eastern North American seismic zones: Lithosphere, v. 2, no. 2, p. 76-83, doi: 10.1130/L65.1.

McKenna, Jason, Stein, Seth, and Stein, C.A., 2007, Is the New New Madrid seismic zone hotter and weaker than its surroundings?, in Stein, Seth, and Mazzotti, S., eds., Continental Intraplate Earthquakes: Boulder, Colo., GSA Special Paper 425, p. 167-175.

McKeown, F.A., and Diehl, S.F., 1994, Evidence of contemporary and ancient excess fluid pressure in the New Madrid seismic zone of the Reelfoot Rift, central United States, in Shedlock, K.M., and Johnston, A.C., eds., Investigations of the New Madrid Seismic Zone: U.S. Geological Survey Professional Paper 1538-N, 24 p.

Milne, G.A., Davis, J.L., Mitrovica, J.X., Scherneck, H.-G., Johansson, J.M., Vermeer, M., and Koivula, H., 2001, Space-geodetic constraints on glacial isostatic adjustment in Fennoscandia: Science, v. 291, p. 2381-2385. 
Newman, A.V., 2000, Geodetic and seismic studies of the New Madrid Seismic Zone and implications for earthquake recurrence and seismic hazard: Evanston, Northwestern University, Ph.D. dissertation, 158 p.

Newman, A.V., Stein, Seth, Weber, J.C., Engeln, J.F., Mao, Ailin, and Dixon, T.H., 1999, Slow deformation and implied long earthquake recurrence intervals from GPS surveys across the New Madrid seismic zone: Science, v. 284, p. 619-621.

Nocquet, J.-M., Calais, E., and Parsons, B., 2005, Geodetic constraints on glacial isostatic adjustment in Europe: Geophysical Research Letters, v. 32, no. L06308.

Panno, S.V., Lundstrom, C.C., Hackley, K.C., Curry, B.B., Fouke, B.W., and Zhang, Zaofeng, 2009, Major earthquakes recorded by speleothems in midwestern U.S. caves: Bulletin of the Seismological Society of America, v. 99, p. 2147-2154, doi: 10.1785/0120080261.

Pollitz, F.F., Kellogg, Louise, and Burgmann, Roland, 2001, Sinking mafic body in a reactivated lower crust: A mechanism for stress concentration at the New Madrid seismic zone: Bulletin of the Seismological Society of America, v. 91, no. 6, p. 1882-1897, doi: 10.1785/0120000277.

Sbar, M.L., and Sykes, L.R., 1973, Contemporary compressive stress and seismicity in eastern North America: an example of intra-plate tectonics: Geological Society of America, v. 84, p. 1861-1882, doi:10.1130/0016-7606(1973)84<1861.

Sella, G.F., Dixon, T.H., and Mao, Ailin, 2002, REVEL: A model for Recent plate velocities from space geodesy: Journal of Geophysical Research, v. 107, no. B4, 30 p.

Simmons, N.A., Forte, A.M., and Grand, S.P., 2006, Constraining mantle flow with seismic and geodynamic data: A joint approach: Earth Planetary Science Letters, v. 246, p. 109 - 124.

Simpson, R.W., 1997, Quantifying Anderson's fault types: Journal of Geophysical Research, v. 102, no. B8, p. 17,909-17,919.

Smalley, R., Ellis, M.A., Paul, J., and VanArdsale, R.B., 2005, Space geodetic evidence for rapid strain rates in the New Madrid seismic zone of central USA: Nature, v. 453, no. 23, p. 10881090.

Snay, R.A., Ni, J.F., and Neugebauer, H.C., 1994, Geodetically derived strain across the northern New Madrid Seismic Zone: U.S. Geological Survey Professional Paper 1538-F-G.

Stein, Seth, and Liu, Mian, 2009, Long aftershock sequences within continents and implications for earthquake hazard assessment: Nature, v. 462, p. 87-89.

Stuart, W.D., Hildenbrand, T.G., and Simpson, R.W., 1997, Stressing of the New Madrid seismic zone by a lower crust detachment fault: Journal of Geophysical Research, v. 102, no. B12, p. $27,623-27,633$. 
Sykes, L.R., 1978, Intraplate seismicity, reactivation of pre-existing zones of weakness, alkaline magnetism, and other tectonics post-dating continental fragmentation: Reviews of Geophysics and Space Physics, v. 16, no. 4, p. 621-688.

Townend, J., and Zoback, M.D., 2000, How faulting keeps the crust strong: Geology, v. 28, no. 5, p. 399-402.

Tuttle, M.P., and Hartleb, Ross, 2012, Appendix E-CEUS paleoliquefaction database, uncertainties associated with paleoliquefaction data, and guidance for seismic source characterization, in Central Eastern United States-Seismic Source Characterization for Nuclear Facilities, Technical Report: EPRI, Palo Alto, Calif., U.S. DOE, and U.S. NRC, 135 p. plus database. Appendix E and other products of the CEUS Seismic Source Characterization Project available at http://www.ceus-ssc.com.

Tuttle, M.P., Schweig, E.S., III, Campbell, Janice, Thomas, P.M., Sims, J.D., and Lafferty, R.H., III, 2005, Evidence for New Madrid earthquakes in A.D. 300 and 2350 B.C.: Seismological Research Letters, v. 76, p. 489-501, doi:10.1785/gssrl.76.4.489.

Weber, J., Stein, S., and Engeln, J., 1998, Estimation of strain accumulation in the New Madrid seismic zone from GPS geodesy: Tectonics, v. 17, p. 250-266.

Williams, S.D.P., 2008, CATS : GPS coordinate time series analysis software" GPS Solutions, v. 12 , no. 2 , p. 147-153.

Wu, Patick, and Johnston, Paul, 2000, Can deglaciation trigger earthquakes in N. America?: Geophysical Research Letters, v. 27, no.9, p. 1323-1326.

Zhang, Qie, Sandvol, Eric, and Liu, Mian, 2009a, Lithospheric velocity structure of the New Madrid Seismic Zone: A joint teleseismic and local P tomographic study: Geophysical Research Letters, v. 36, no. L11305, 6 p.

Zhang, Qie, Sandvol, Eric, and Liu, Mian, 2009b, Tomographic Pn velocity and anisotropy structure in the central and eastern United States: Bulletin of the Seismological Society of America, v. 99, no. 1, p. 422-427.

Zoback, M.L., 1992, Stress field constraints on intraplate seismicity in eastern North America: Journal of Geophysical Research, v. 97, no. B8, p. 11761-11782.

Zoback, M.D., and Harjes, H.-P., 1997, Injection-induced earthquakes and crustal stress at $9 \mathrm{~km}$ depth at the KTB deep drilling site, Germany: Journal of Geophysical Research, v. 102, no. B8, p. 18,477-18,491, doi:10.1029/96JB02814.

Zoback, M.D., and Zoback, M.L., 1981, State of stress and intraplate earthquakes in the United States: Science, v. 213, no. 4503, p. 96-104, DOI: 10.1126/science.213.4503.96. 
Zoback, M.L., and Zoback, Mark, 1980, State of stress in the conterminous United States: Journal of Geophysical Research, v. 85, no. B11, p. 6113-6156.

Zoback, M.L., and Zoback, M.D., 1989, Regional tectonic stress field of the continental U.S., in Pakiser, Louis, and Mooney, W.D., eds., Geophysical Framework of the Continental U.S.: Geological Society of America Memoir, 172, p. 523-539.

Zumberge, J.F., Heflin, M.B., Jefferson, D.C., Watkins, M.M., and Webb, F.H., 1997, Precise point positioning for the efficient and robust analysis of GPS data from large networks: Journal of Geophysical Research, v. 102, no. B3, p. 5005-5017. 